\title{
Bioactive compounds from marine actinomycetes
}

\author{
Renu Solanki $\cdot$ Monisha Khanna $\cdot$ Rup Lal
}

Received: 18 November 2007 / Accepted: 12 June 2008

\begin{abstract}
Actinomycetes are one of the most efficient groups of secondary metabolite producers and are very important from an industrial point of view. Among its various genera, Streptomyces, Saccharopolyspora, Amycolatopsis, Micromonospora and Actinoplanes are the major producers of commercially important biomolecules. Several species have been isolated and screened from the soil in the past decades. Consequently the chance of isolating a novel actinomycete strain from a terrestrial habitat, which would produce new biologically active metabolites, has reduced. The most relevant reason for discovering novel secondary metabolites is to circumvent the problem of resistant pathogens, which are no longer susceptible to the currently used drugs. Existence of actinomycetes has been reported in the hitherto untapped marine ecosystem. Marine actinomycetes are efficient producers of new secondary metabolites that show a range of biological activities including antibacterial, antifungal, anticancer, insecticidal and enzyme inhibition. Bioactive compounds from marine actinomycetes possess distinct chemical structures that may form the basis for synthesis of new drugs that could be used to combat resistant pathogens.
\end{abstract}

R. Solanki ${ }^{1}$ M. Khanna ${ }^{1} \cdot$ R. Lal ${ }^{2}(\bowtie)$

${ }^{1}$ Acharya Narendra Dev College,

University of Delhi, Govindpuri,

Kalkaji, New Delhi - 110 019, India

${ }^{2}$ Molecular Biology Lab,

Department of Zoology, University of Delhi,

Delhi - 110 007, India

E-mail: ruplal@gmail.com
Keywords Marine actinomycetes $\cdot$ Bioactive compounds

\section{Introduction}

Microbial natural products are an important source of both existing and new drugs. Among the producers of commercially important metabolites, bacteria have proven to be a prolific source with a surprisingly small group of taxa accounting for the vast majority of compounds discovered till date [1]. Among these, Actinomycetes are the most economically and biotechnologically priceless prokaryotes. Representative genera of actinomycetes include Streptomyces, Actinomyces, Arthrobacter, Corynebacterium, Frankia, Micrococcus, Micromonospora and several others. Secondary metabolites produced by actinomycetes possess a wide range of biological activities [1-4]. The genus Streptomyces alone produces a large number of bioactive molecules [5-128]. It has an enormous biosynthetic potential that remains unchallenged without a potential competitor among other microbial groups. A large number of Streptomyces spp. have been isolated and screened from soil in the past several decades $[129,130]$. Consequently the chances of isolating a novel Streptomyces strain from terrestrial habitats have diminished. Above 500 species of Streptomyces account for $70-80 \%$ of relevant secondary metabolites as shown in Table 1 [5-127], with small contributions from other genera, such as Saccharopolyspora, Amycolatopsis, Micromonospora and Actinoplanes. An important reason for discovering novel secondary metabolites is to circumvent the problem of resistant pathogens, which are no longer susceptible to the currently used drugs [131, 132]. The number of deaths due to these clever pathogenic organisms is on the rise. Secondary metabolites from marine 
Table 1 Secondary metabolites produced by actinomycetes

\begin{tabular}{|c|c|c|c|}
\hline S. No. & Compound & Source & Activity \\
\hline 1. & Erythromycin [5] & Saccharopolyspora erythrae & Antibacterial \\
\hline 2. & Rhamnose [6] & Saccharopolyspora spinosa & $\begin{array}{l}\text { Essential component of insect control agent } \\
\text { compound spinosad }\end{array}$ \\
\hline 3. & Zorbamycin [7] & Streptomyces flavovirdis & Antitumor \\
\hline 4. & Kanamycin [8] & Streptomyces kanamyceticus 12-6 & Antibacterial \\
\hline 5. & Kanglemycin C (K-C) [9] & $\begin{array}{l}\text { Nocardia mediterranei var. } \\
\text { kanglensis } 1747-64\end{array}$ & Immunosuppressive \\
\hline 6. & Rapamycin [10] & Streptomyces hygroscopicus & Antifungal \\
\hline 7. & Pandavir (nigericin) [11] & Streptomyces hygroscopicus & Affects ion transport and ATPase activity \\
\hline 8. & FK520 Ascomycin [12] & $\begin{array}{l}\text { Streptomyces hygroscopicus var. } \\
\text { ascomyceticus }\end{array}$ & Antifungal, immunosuppressive, neutrophic \\
\hline 9. & Himastatin [13] & Streptomyces hygroscopicus & Antitumor \\
\hline 10. & Jinggangmycin [14] & Streptomyces hygroscopicus & Antifungal \\
\hline 11. & Oxytetracycline [15] & Streptomyces rimosus & Antibacterial \\
\hline 12. & Amphotericin B [16] & Streptomyces nodosus & Antifungal \\
\hline 13. & Asukamycin [17] & Streptomyces nodosus subsp. asukaensis & Antibacterial \\
\hline 14. & Tylosin [18] & Streptomyces fradiae & Antibacterial \\
\hline 15. & Urdamycin A [19] & Streptomyces fradiae & Antitumor \\
\hline 16. & Fosfomysin [20] & Streptomyces fradiae & Antibacterial \\
\hline 17. & CE-108 [21] & Streptomyces diastaticus & Antifungal \\
\hline 18. & Rimocidin [22] & Streptomyces diastaticus var. 108 & Antifungal \\
\hline 19. & Shurimycins A and B [23] & Streptomyces hygroscopicus & Antibacterial, antifungal \\
\hline 20. & Chloramphenicol [24] & Streptomyces venezuelae & Antibacterial \\
\hline 21. & Rifamycin [25] & Amycolatopsis mediterranei U-32 & Antibacterial \\
\hline 22. & Amythiamicins [26] & Amycolatopsis sp. & Antibacterial \\
\hline 23. & Cyclo (L-leucyl-1-prolyl) [27] & Streptomyces sp. KH614 & $\begin{array}{l}\text { Antileukemic, anti-VRE } \\
\text { (vancomycin-resistant enterococci) }\end{array}$ \\
\hline 24. & Ipomicin [28] & Streptomyces ipomoeae group III & Antibacterial \\
\hline 25. & Streptomycin [29] & Streptomyces griseus & Antibacterial \\
\hline 26. & Valinomycin [30] & Streptomyces griseus & Mitochondrial toxin \\
\hline 27. & Griseorhodin [31] & Streptomyces griseus FCRC-57 & Telomerase inhibitor \\
\hline 28. & Fredericamycin A [32] & Streptomyces griseus FCRC-48 & Antitumor \\
\hline 29. & Capuramycin [33] & Streptomyces griseus SANK 60196 & Antibacterial \\
\hline 30. & Frigocyclinone [34] & Streptomyces griseus strain NTK 97 & Antibacterial \\
\hline 31. & Clorobiocin [35] & Streptomyces coelicolor & Inhibitor of bacterial gyrase \\
\hline 32. & Meilingmycin [36] & Streptomyces nanchangensis & Antiparasitic \\
\hline 33. & Nanchangmycin [36] & Streptomyces nanchangensis & Insecticidal \\
\hline 34. & Eremomycin $[37,38]$ & $\begin{array}{l}\text { Amycolatopsis orientalis subsp. } \\
\text { eremomycini }\end{array}$ & Antimicrobial \\
\hline 35 . & Nikkomycins [39] & Streptomyces ansochromogenus & Antifungal \\
\hline 36. & Avilamycin A [40] & Streptomyces viridochromogenes Tu57 & Antibacterial \\
\hline 37. & Tubelactomicin A [41] & Nocardia sp. & Antibacterial \\
\hline
\end{tabular}


Table 1 (Continued)

\begin{tabular}{|c|c|c|c|}
\hline S. No. & Compound & Source & Activity \\
\hline 38. & Benzanthrins A and B [42] & Nocardia lurida & Antibacterial \\
\hline 39. & Azureomycins A and B [43] & Pseudonocardia azurea nov. sp. & Antibacterial \\
\hline 40. & Nogalamycin [44] & Streptomyces nogalater & Antibacterial \\
\hline 41. & $\begin{array}{l}\text { Aclacinomycin A } \\
\text { (aclarubicin) [45] }\end{array}$ & Streptomyces galilaeus & Antitumor \\
\hline 42. & Cinerubin R [46] & Streptomyces eurythermus & Antibacterial \\
\hline 43. & Scopafungin [47] & $\begin{array}{l}\text { Streptomyces hygroscopicus var. enhygrus } \\
\text { var. nova UC- } 2397\end{array}$ & Antifungal, antibacterial \\
\hline 44. & Spiramycin [48] & Streptomyces ambofaciens & Antibacterial \\
\hline 45. & Pristinamycin I [49] & Streptomyces pristinaespiralis & Antibacterial \\
\hline 46. & Lankacidin [50] & Streptomyces rochei & Antibacterial \\
\hline 47. & Lankamycin [50] & Streptomyces rochei & Antibacterial \\
\hline 48. & Actinomycin C [51] & Streptomyces chrysomallus & Antitumor \\
\hline 49. & Duanomycin [52] & Streptomyces sp. & Antitumor \\
\hline 50. & Midecamycin [53] & Streptomyces mycarofaciens & Antibacterial \\
\hline 51. & Avermectin [54] & Streptomyces avermitilis & Anthelminthic \\
\hline 52. & Oligomycin [55] & Streptomyces avermitilis & Cell growth inhibitor \\
\hline 53. & Resormycin [56] & Streptomyces platensis & Herbicidal, antifungal \\
\hline 54. & Ileumycin [57] & Streptomyces lavendulae & Antifungal \\
\hline 55. & Mitomycin C [58] & Streptomyces lavendulae & Antitumor \\
\hline 56. & Lomofungin [59] & Streptomyces lomodensis & Antifungal, antibacterial \\
\hline 57. & Kalafungin [60] & $\begin{array}{l}\text { Streptomyces tanashiensis strain } \\
\text { Kala UC5063 }\end{array}$ & Antifungal, antibacterial, antiprotozoal \\
\hline 58. & Thiamycins [61] & $\begin{array}{l}\text { Streptomyces michiganensis var. } \\
\text { amylolyticus var. nova }\end{array}$ & Anthelminthic, antiprotozoal \\
\hline 59. & Axenomycins [62] & Streptomyces lisandri nov. sp. & Anthelminthic, antiprotozoal, antifungal \\
\hline 60. & Neihumicin [63] & Micromonospora neihuensis & Cytotoxic \\
\hline 61. & Fortimicin A (Astromicin) [64] & Micromonospora olivasterospora & Antibacterial \\
\hline 62. & Gentamicin [65] & Micromonospora purpurea var. violaceae & Antibacterial \\
\hline 63. & Tetracycline [66] & Streptomyces aureofaciens & Antibacterial \\
\hline 64. & Monomycin $[67,68]$ & Actinomyces circulatus var. monomycini & Antibacterial \\
\hline 65. & PC-766 B [69] & Nocardia brasiliensis & Antioxidant \\
\hline 66. & Medecamycin $[70,71]$ & Streptomyces mycarofaciens & Antibacterial \\
\hline 67. & Dunaimycins [72] & Streptomyces diastatochromogenes & Immunosuppressive, antimicrobial \\
\hline 68. & Novobiocin [73] & Streptomyces niveus & Antibacterial \\
\hline 69. & Carminomycin [74] & Actinomadura carminata & Antitumor \\
\hline 70. & Maduramycins [75] & Actinomadura rubra & Antibacterial \\
\hline 71. & MM461156 [76] & Actinomadura pelletieri & Antiviral, antibacterial \\
\hline 72. & Verucopeptin [77] & Actinomadura verrucosospora & Antitumor \\
\hline 73. & Saptomycins [78] & Streptomyces sp. HP 530 & Antitumor, antimicrobial \\
\hline 74. & Oxaprapalines B, D, G [79] & Streptomyces sp. G324 & Antitumor \\
\hline 75. & Lavendamycin [80] & Streptomyces lavendulae & Antitumor \\
\hline 76. & Chlorocarcins A, B, C [81] & Streptomyces lavendulae No. 314 & Antitumor, antibacterial \\
\hline
\end{tabular}


Table 1 (Continued)

\begin{tabular}{|c|c|c|c|}
\hline S. No. & Compound & Source & Activity \\
\hline 77. & Mimosamycins [81] & Streptomyces lavendulae No. 314 & Antibacterial \\
\hline 78. & Lavendomycin [82] & Streptomyces lavendulae & Antibacterial \\
\hline 79. & Sohbumycin [83] & Streptomyces sp. 82-85 & Antitumor, antibacterial \\
\hline 80. & $\begin{array}{l}\text { Furaquinocins C, D, E, F, G, H } \\
{[84]}\end{array}$ & Streptomyces sp. KO 3988 & Antitumor \\
\hline 81. & Arizonins A1 and B1 [85] & Actinoplanes arizonaensis sp. nov. & Antibacterial \\
\hline 82. & Coloradocin [86] & Actinoplanes coloradoensis sp. nov. & Antibacterial \\
\hline 83. & Teichomycins [87] & Actinoplanes teichomyceticus nov. sp. & Antibacterial \\
\hline 84. & Lipiarmycin [88] & Actinoplanes deccanensis nov. sp. & Antibacterial \\
\hline 85. & Candiplanecin [89] & $\begin{array}{l}\text { Ampullariella reguralis subsp. } \\
\text { mannitophila subsp. nov. }\end{array}$ & Antifungal \\
\hline 86. & Victomycin [90] & $\begin{array}{l}\text { Streptosporangium violaceochromogenes } \\
\text { nov. sp. }\end{array}$ & Antitumor, antibacterial \\
\hline 87. & $\begin{array}{l}\text { Maggiemycin and } \\
\text { anhydromaggiemycin [91] }\end{array}$ & Streptomyces sp. & Antitumor \\
\hline 88. & Gilvusmycin [92] & Streptomyces sp. & Antitumor \\
\hline 89. & Kazusamycin [93] & Streptomyces sp. & Antitumor \\
\hline 90. & Okicenone [94] & Streptomyces sp. & Antitumor \\
\hline 91. & Hydramycin [95] & Streptomyces violaceus & Antitumor \\
\hline 92. & Musacin C [96] & Streptomyces griseovirdis & Anthelminthic, antiviral \\
\hline 93. & Kanchanamycins [97] & Streptomyces olivaceus & Antifungal, antibacterial \\
\hline 94. & Elloramycin [98] & Streptomyces olivaceus & Antitumor \\
\hline 95. & Fattiviracin A1 [99] & Streptomyces microflavus & Antiviral \\
\hline 96. & FK $506[100]$ & Streptomyces tsukubaensis & Antiviral \\
\hline 97. & Retamycin [101] & Streptomyces olindensis & Antitumor \\
\hline 98. & Manumycin [102] & Streptomyces parvulus & Antitumor, enzyme inhibitory \\
\hline 99. & Granaticin $[103,104]$ & Streptomyces thermoviolaceus & Antibacterial \\
\hline 100. & Pimaricin [105] & Streptomyces natalensis & Antifungal \\
\hline 101. & Virginiamycin M [106, 107] & Streptomyces virginae & Antibacterial \\
\hline 102. & $\begin{array}{l}\text { Daptomycin (commercialized } \\
\text { as Cubicin) [108] }\end{array}$ & Streptomyces roseosporus & Antibacterial \\
\hline 103. & Enduracidin [109] & Streptomyces fungicidicus B5477 & Antibacterial \\
\hline 104. & Apramycin [110] & Streptomyces tenebrabrius UD2 & Antibacterial \\
\hline 105. & Mithramycin [111] & Streptomyces argillaceus & Antitumor \\
\hline 106. & Blasticidin S [112] & Streptomyces griseochromogenes & Antifungal \\
\hline 107. & Leptomycin [113] & Streptomyces lividans & Antifungal, antitumor \\
\hline 108. & Landomycin E [114] & Streptomyces globisporus & Antitumor \\
\hline 109. & Phenalinolactones A-D [115] & Streptomyces sp. & Antibacterial \\
\hline 110. & Pipalamycin [116] & Sreptomyces sp. & Apoptosis inducer, antibacterial \\
\hline 111. & Biphenomycin A and B [117] & Streptomyces griseorubiginosus & Antibacterial \\
\hline 112. & Streptocidins A-D [118] & Streptomyces sp. Tu6071 & Antibacterial \\
\hline 113. & Zelkovamycin [119] & Streptomyces sp. K96-0670 & Antibacterial \\
\hline 114. & Methylsulfomycin I [120] & Streptomyces sp. RSP9 & Antibacterial \\
\hline
\end{tabular}


Table 1 (Continued)

\begin{tabular}{llll}
\hline S. No. & Compound & Source & Activity \\
\hline 115. & YM-216391 [121] & Streptomyces nobilis & Anticancer \\
116. & RP-1776 [122] & Streptomyces sp. & $\begin{array}{l}\text { Inhibit binding of platelet derived growth } \\
\text { factor to its receptor }\end{array}$ \\
117. & RS-22 A, B and C [123] & Streptomyces violaceusniger & Antifungal, antibacterial \\
118. & Vicenistatin [124] & Streptomyces sp. Tu6239 & Antitumor \\
119. & Ripromycin [125] & Streptomyces sp. & Antibacterial, antitumor \\
120. & Vinylamycin [126] & Streptomyces sp. & Antibacterial \\
121. & Cephamycin C [127] & Streptomyces lactamdurans & Antibacterial \\
\hline
\end{tabular}

actinomycetes may form the basis for the synthesis of novel therapeutic drugs, which may be efficient to combat a range of resistant microbes [133, 134].

Existence of cousins of terrestrial actinomycetes has been reported in the relatively untapped marine ecosystem. The immense diversity of this habitat along with it's underexploitation is the fundamental reason for attracting researchers towards it for discovering novel metabolite producers. Actinomycetes comprise about $10 \%$ of the bacteria colonizing marine aggregates and can be isolated from marine sediments [135]. Many actinomycete isolates from deep oceans contain non-ribosomal polyketide synthetase (NRPS) and polyketide synthetase (PKS) pathways, the hallmarks of secondary metabolite production [136]. There is an occurrence of distinct rare genera in the marine ecosystem as evidenced by the taxonomic description of the first marine actinomycete Rhodococcus marinonascens [137]. Actinomycetes have also been isolated from free swimming as well as sessile marine vertebrates and invertebrates [135]. Unusual actinomycetes belonging to Micrococceae, Dermatophilaceae and Gordoniaceae, have been isolated from sponges [133]. Tetrodotoxin-producing actinomycete has been isolated from puffer fish ovaries [138], the organism was found to be most closely related to Nocardiopsis dassonvillei.

Researchers are finding new genera from marine environments on a regular basis and discovering new metabolite producers never reported earlier. Actinomycete genera identified by cultural and molecular techniques from different marine ecological niches include Actinomadura, Actinosynnema, Amycolatopsis, Arthrobacter, Blastococcus, Brachybacterium, Corynebacterium, Dietzia, Frankia, Frigoribacterium, Geodermatophilus, Gordonia, Kitasatospora, Micromonospora, Micrococcus, Microbacterium, Mycobacterium, Nocardioides, Nocardiopsis, Nonomurea, Psuedonocardia, Rhodococcus, Saccharopolyspora, Salinispora, Serinicoccus, Solwaraspora, Streptomyces, Streptosporangium, Tsukamurella, Turicella, Verrucosispora and Williamsia [135]. Inspite of improvements being made in the cultural methods for the isolation of rare marine actinomycetes, many of these organisms still remain unculturable and have to be detected by using molecular techniques [139, 140]. Metagenomic methods are useful for characterizing microbes that cannot be cultivated and can also be used to isolate their genes [141].

\section{Secondary metabolites from marine actinomycetes}

Marine actinomycetes have proven to be efficient producers of new secondary metabolites as shown in Table 2 [142-182], which show a range of biological activities such as antifungal, antitumor, antibacterial, immunosuppressive, insecticidal and enzyme inhibition, to name a few.

Secondary metabolites produced by marine actinomycetes can be classified on the basis of their chemical structure as follows:

\section{Terpenes and terpenoids}

The most chemically diverse pool of secondary metabolites in nature is constituted by terpenes [183]. In 1956, novobiocin was isolated as the first antibiotic with a terpenoid side chain from Streptomyces niveus [184]. After this, the list of these compounds isolated from soil actinomycetes has increased as listed in Table 3 [185-193].

Terpenes are not only produced by the soil actinomycetes but also from the marine habitants as evidenced by the following compounds:

I. Azamerone [142] is a meroterpenoid produced by a new marine bacterium related to the genus Streptomyces. It appears to be the first natural product with a phthalazione ring (Fig. 1).

II. Three new pyrrolosesquiterpenes, glaciapyrroles A, B and C [143] are produced by a Streptomyces strain (NPSOO 8187). These compounds show antibacterial 
Table 2 Bioactive compounds produced by marine actinomycetes

\begin{tabular}{|c|c|c|c|c|}
\hline S. No. & Chemical group & Compound & Source & Activity \\
\hline 1. & Meroterpenoid & Azamerone [142] & Streptomyces sp. & None \\
\hline 2. & Pyrrolosesquiterpenes & Glaciapyrroles A, B and C [143] & $\begin{array}{l}\text { Streptomyces sp. } \\
\text { NPS008187 }\end{array}$ & Antibacterial \\
\hline 3. & $\begin{array}{l}\text { Amorphane } \\
\text { sesquiterpenes [144] }\end{array}$ & $\begin{array}{l}10 \alpha, 15 \text {-dihydroxyamorph-4-en-3-one, } \\
10 \alpha, 11 \text {-dihydroxyamorph-4-ene and } \\
5 \alpha, 10 \alpha, 11 \text {-trihydroxyamorphan-3-one } \\
{[144]}\end{array}$ & Streptomyces sp. M491 & None \\
\hline 4. & Sesquiterpene & Neomarinone [145] & Strain CNH-099 & Cytotoxic \\
\hline 5. & Polyketide & Saliniketal A, saliniketal B $[146,147]$ & Salinispora arenicola & Anticancer \\
\hline 6. & Polyketide & Abyssomicin C [148] & Verrucosispora & Antibacterial \\
\hline 7. & Polyketide & SBR-22 [149] & $\begin{array}{l}\text { Steptomyces psommoticus } \\
\text { BT408 }\end{array}$ & Antibacterial \\
\hline 8. & Polyketide & Daryamides [150] & Streptomyces sp. CNQ-085 & Anticancer, antifungal \\
\hline 9. & Polyketide & Actinofuranones A and B [151] & Streptomyces sp. & Cytotoxic \\
\hline 10. & Peptide & Mechercharmycins [152] & Thermoactinomyces sp. & Antitumor \\
\hline 11. & Peptide & Thiocoraline [153] & Micromonospora & Anticancer, antibacterial \\
\hline 12. & Peptide & CyclomarinA [154] & Streptomyces sp. & $\begin{array}{l}\text { Anti-inflammatory, } \\
\text { antiviral }\end{array}$ \\
\hline 13. & Peptide & Piperazimycins [155] & Streptomyces sp. & Anticancer \\
\hline 14. & Peptide & $\begin{array}{l}\text { Dehydroxynocardamine and } \\
\text { desmethylenylnocardamine [156] }\end{array}$ & Streptomyces sp. & $\begin{array}{l}\text { Enzyme sortase B } \\
\text { inhibitor }\end{array}$ \\
\hline 15. & Peptide & Urukthapelstatin [157] & $\begin{array}{l}\text { Mechercharimyces } \\
\text { asporophorigenes } \\
\text { YM11-542 }\end{array}$ & Anticancer \\
\hline 16. & Peptide & Salinamides A and B [158] & Streptomyces sp. & $\begin{array}{l}\text { Antibacterial, } \\
\text { anti-inflammatory }\end{array}$ \\
\hline 17. & Caprolactone & $\begin{array}{l}\text { R-10-methyl-6-undecanolide }(6 \mathrm{R}, 10 \mathrm{~S}) \text { - } \\
\text { 10-methyl-6-dodeconolide [159] }\end{array}$ & Streptomyces sp. B6007 & Phytotoxic, anticancer \\
\hline 18. & Butenolide & Butenolide [160] & $\begin{array}{l}\text { Streptoverticillium } \\
\text { luteoverticillatum }\end{array}$ & Anticancer \\
\hline 19. & Polycyclic xanthone & IB-00208 [161] & Actinomadura & Anticancer, antibacterial \\
\hline 20. & Piericidin & Piericidins C7 and C8 [162] & Streptomyces & Anticancer \\
\hline 21. & Quinone & Resistomycin [163] & $\begin{array}{l}\text { Streptomyces corchorusii } \\
\text { AUBN(1)/7 }\end{array}$ & Antiviral \\
\hline 22. & Quinone & Tetracenomycin D [164] & $\begin{array}{l}\text { Streptomyces corchorusii } \\
\text { AUBN(1)/7 }\end{array}$ & Anticancer, antibacterial \\
\hline 23. & Quinone & Resistoflavine $[165,166]$ & $\begin{array}{l}\text { Streptomyces chibaensis } \\
\operatorname{AUBN}(1) / 7\end{array}$ & Anticancer, antibacterial \\
\hline 24. & Quinone & Komodoquinone A [167] & Streptomyces sp. K53 & Neuritogenic activity \\
\hline 25. & Quinone & Himalomycins A and B [168] & Streptomyces sp. B6921 & Antibacterial \\
\hline 26. & Quinone & Helquinoline [169] & Janibacter limosus & Antibacterial \\
\hline 27. & Quinone & Chlorinated dihydroquinones [170] & CNQ-525 & Anticancer, antibacterial \\
\hline 28. & Macrolide & Chalcomycin A [144] & Streptomyces sp. M491 & None \\
\hline 29. & Macrolide & Arenicolide A $[147,171]$ & Salinispora arenicola & Antibacterial \\
\hline 30. & Macrolide & Marinomycins [172] & Marinispora & Anticancer, antibacterial \\
\hline
\end{tabular}


Table 2 (Continued)

\begin{tabular}{|c|c|c|c|c|}
\hline S. No. & Chemical group & Compound & Source & Activity \\
\hline 31. & Alkaloid & K252c and arcyriaflavin A [173] & Z (2)0392 & Anticancer \\
\hline 32. & Ester & Bonactin [174] & Streptomyces sp. BD21-2 & Antibacterial, antifungal \\
\hline 33. & Manumycin derivatives & Chinikomycins A and B [175] & Streptomyces sp. M045 & Anticancer \\
\hline 34. & Complex compounds & Trioxacarcins $[176]$ & $\begin{array}{l}\text { Streptomyces ochraceus } \\
\text { and Streptomyces } \\
\text { bottropensis }\end{array}$ & Anticancer, antimalarial \\
\hline 35. & Methylpyridine & Streptokordin [177] & $\begin{array}{l}\text { Streptomyces sp. } \\
\text { KORDI-3238 }\end{array}$ & Anticancer \\
\hline 36. & $\begin{array}{l}\text { Gamma lactam beta } \\
\text { lactone }\end{array}$ & Salinosporamide A $[147,178]$ & Salinispora tropica & Anticancer \\
\hline 37. & Macrocyclic lactam & Aureoverticillactam [179] & $\begin{array}{l}\text { Streptomyces } \\
\text { aureoverticillaris }\end{array}$ & Anticancer \\
\hline 38. & Enzyme inhibitor & Alpha-amylase inhibitor [180] & $\begin{array}{l}\text { Streptomyces } \\
\text { corchorusii subsp. } \\
\text { rhodomarinus subsp. nov }\end{array}$ & Enzyme Inhibition \\
\hline 39. & Enzyme inhibitor & Pyrostatins A and B [181] & Streptomyces sp. SA-3501 & $\begin{array}{l}\mathrm{N} \text {-acetyl-beta- } \\
\text { glucosaminidase inhibition }\end{array}$ \\
\hline 40. & Enzyme inhibitor & Pyrizinostatin [182] & Streptomyces sp. SA-2289 & $\begin{array}{l}\text { Pyroglutamyl peptidase } \\
\text { inhibition }\end{array}$ \\
\hline
\end{tabular}

Table 3 Terpenes produced by soil actinomycetes

\begin{tabular}{llll}
\hline S. No. & Compound & Source & Activity \\
\hline 1. & Pentalenolactone I $[185,186]$ & Streptomyces filipinensis & Antibacterial, immunosupprressive \\
2. & Lavanduquinocin $[185,187]$ & Streptomyces viridochromogenes & Neuronal cell protection \\
3. & Napyradiomycins $[185,188]$ & Chiana rubra & Antibacterial \\
4. & Spirocardins A and B $[185,189]$ & Nocardia sp. SANK 64282 & Antibacterial \\
5. & Benthocyanin A $[185,190]$ & Streptomyces prunicolor & Radical scavenger \\
6. & Benzastatin C $[185,191]$ & Streptomyces nitrosporeus & Antiviral \\
7. & Carquinostatin B $[185,192]$ & Streptomyces exfoliatus & Neuronal cell protection \\
8. & Moenomycin $[185,193]$ & Streptomyces bambergensis & Antibacterial \\
\hline
\end{tabular}

activities. Structures of glaciapyrroles A, B and C are shown in Fig. 2.

III. Amorphane sesquiterpenes [144] (Fig. 3) namely

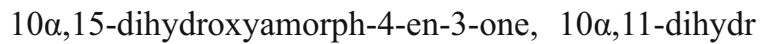

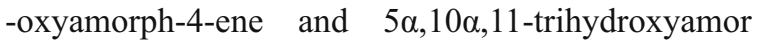
phan-3-one are produced by Streptomyces sp. M491. This is the first report of these sesquiterpenes from bacteria.

IV. Neomarinone [145], a novel metabolite possessing a new sesquiterpene and polyketide-derived carbon skeleton and several derivatives of the marinone class of naphthoquinone antibiotics are produced by a taxonomically novel marine actinomycete (strain CNH-099). These bioactive molecules show moderate cytotoxicity towards human cancer cells.
2. Polyketides

I. Saliniketal A (Fig. 4) and saliniketal B [146, 147], produced by Salinispora arenicola, are inhibitors of ornithine decarboxylase biosynthesis. Inhibition of ornithine decarboxylase production is an important strategy in the control of cancer since high levels of this enzyme lead to uncontrolled proliferation of cells. The Saliniketals are partly related in structure to the rifamycins.

II. Abyssomicin C [148] (Fig. 5) is a polycyclic polyketide produced by Verrucosispora. It targets p-aminobenzoate (PABA) biosynthesis and therefore inhibits folic acid biosynthesis at an early stage as compared to the well-known synthetic sulpha drugs. 
The abyssomicins are the first known bacterial secondary metabolites that can inhibit the biosynthesis of PABA. Targeting PABA production is an attractive strategy for arresting microbial growth since PABA directly leads to the production of folic acid, which is a precursor of purine biosynthesis. Humans lack this pathway; therefore the strategy will not be harmful to humans. Abyssomicin $\mathrm{C}$ shows antibacterial activity against gram-positive bacteria as well as clinical isolates of multiple resistant and vancomycin-resis-

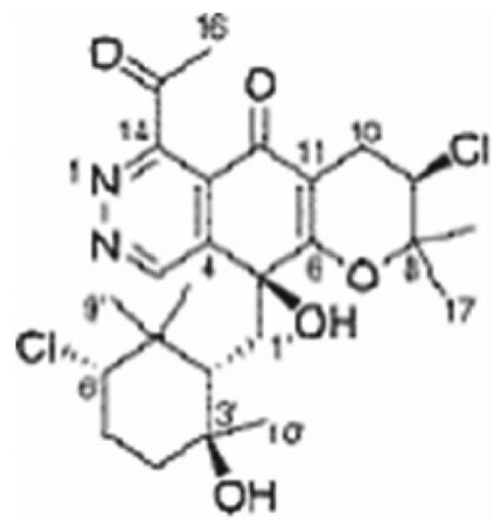

tant Staphylococcus aureus. Abyssomicin C and its analogues thus have a high potential to be developed as antibacterial agents against drug-resistant pathogens.

III. A marine inhabitant known as Streptomyces psommoticus produces antibiotic SBR-22 [149]. It shows antibacterial activity against methicillin-resistant Staphylococcus aureus.

IV. Daryamides [150] (Fig. 6) are cytotoxic polyketides isolated from culture broth of a Streptomyces strain, CNQ-085. These bioactive compounds show weak to moderate cytotoxicity against the human colon carcinoma cell line HCT-116 and very weak antifungal activities against Candida albicans.

V. Actinofuranones A and B [151] (Fig. 7) are isolated from the fermentation broth of a marine bacterium related to Streptomyces genus. Actinofuranones A and B show weak in vitro cytotoxicity against mouse splenocyte T-cells and macrophages.

3. Peptides

I. Mechercharmycins [152] are new bioactive compounds obtained from marine-derived Thermoactinomyces sp. YM3-251. The cyclic structure of mechercharmycin A

Fig. 1 Azamerone

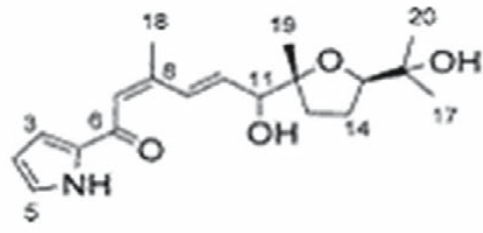

(A)

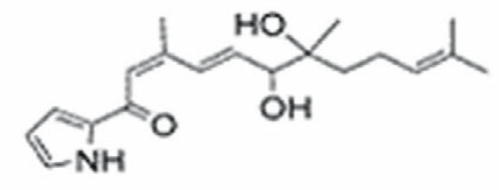

(B)

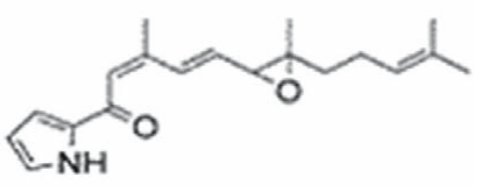

(C)

Fig. 2 Glaciapyrroles A, B, C
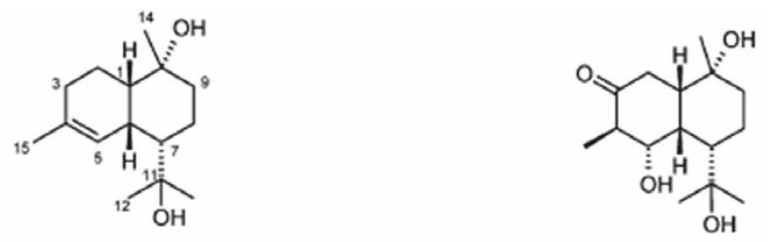

10a, 11-dihydroxyamorph-4-ene

5a, 10a,-11-trihydroxyamorphan-3-one<smiles>CC(C)[C@H]1CCC(C)(O)C2(C)CC(=O)C(CO)=CC12</smiles>

10a-15-dihydroxyamorph-4-en-3-one

Fig. 3 Amorphane sesquiterpenes 


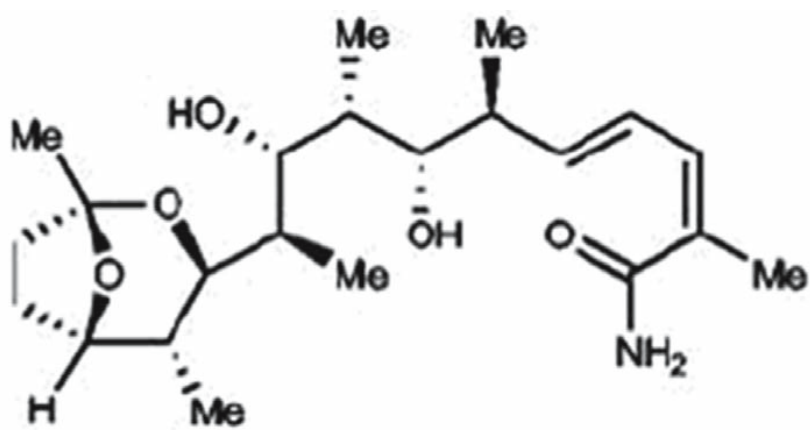

Fig. 4 Saliniketal A

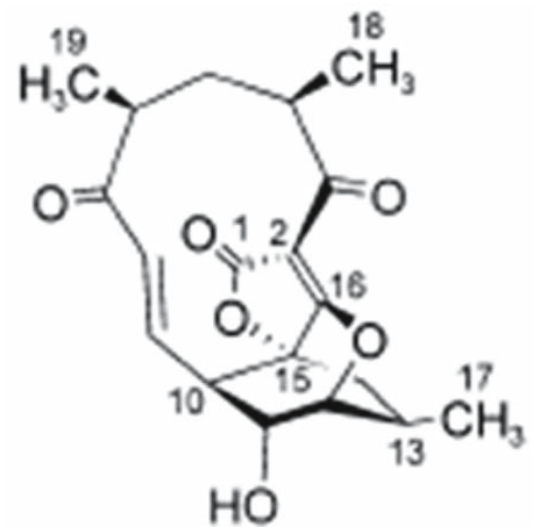

Fig. 5 Abyssomicin C

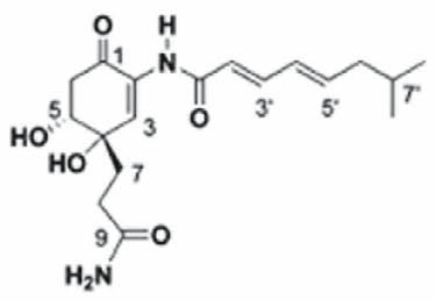

(A)

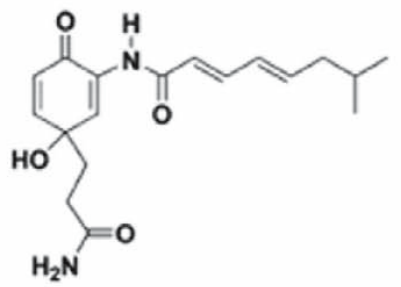

(B)

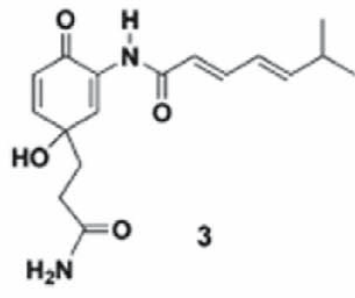

(C)

Fig. 6 Daryamides A, B and C

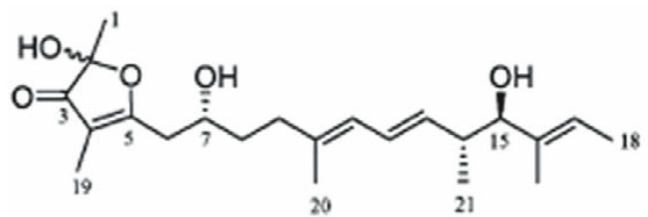

(A)

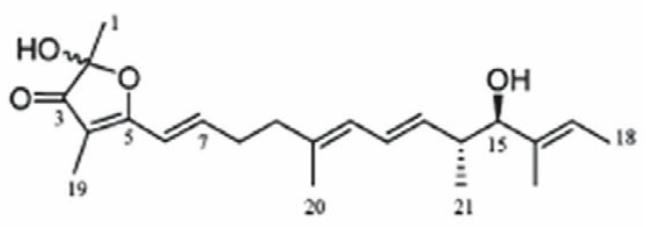

(B)

Fig. 7 Actinofuranones A and B

(Fig. 8) is essential for its strong antitumor activity, since the related compound mechercharmycin B (Fig. 9) does not show such an activity.

II. Thiocoraline [153] is a new depsipeptide isolated from Micromonospora. It shows potent cytotoxicity against P-388, A-549 and MEL cell lines, and also a strong antimicrobial activity against gram-positive microorganisms. This compound binds to supercoiled DNA and inhibits RNA synthesis.

III. Cyclomarins A-C [154] (Fig. 10) are cyclic peptides produced by a Streptomyces sp. They show antiinflammatory and antiviral activities.

IV. Piperazimycins [155] (Fig. 11) are cytotoxic hexadepsipeptides isolated from the fermentation broth of a
Streptomyces sp. Piperazimycin A exhibits potent in vitro cytotoxicity against multiple tumor cell lines.

V. Two cyclic peptides dehydroxynocardamine [156] and desmethylenylnocardamine [156] along with nocardamine have been isolated from a Streptomyces sp. which has been obtained from an unidentified marine sponge. These new compounds exhibit weak inhibition against the enzyme sortase $\mathrm{B}$.

VI. Urukthapelstatin A [157] is a novel cyclic peptide produced by the thermoactinomycete bacterium Mechercharimyces asporophorigenes YM11-542. It inhibits the growth of human lung cancer A54 cells and shows cytotoxicity against a range of human cancer cell lines. 


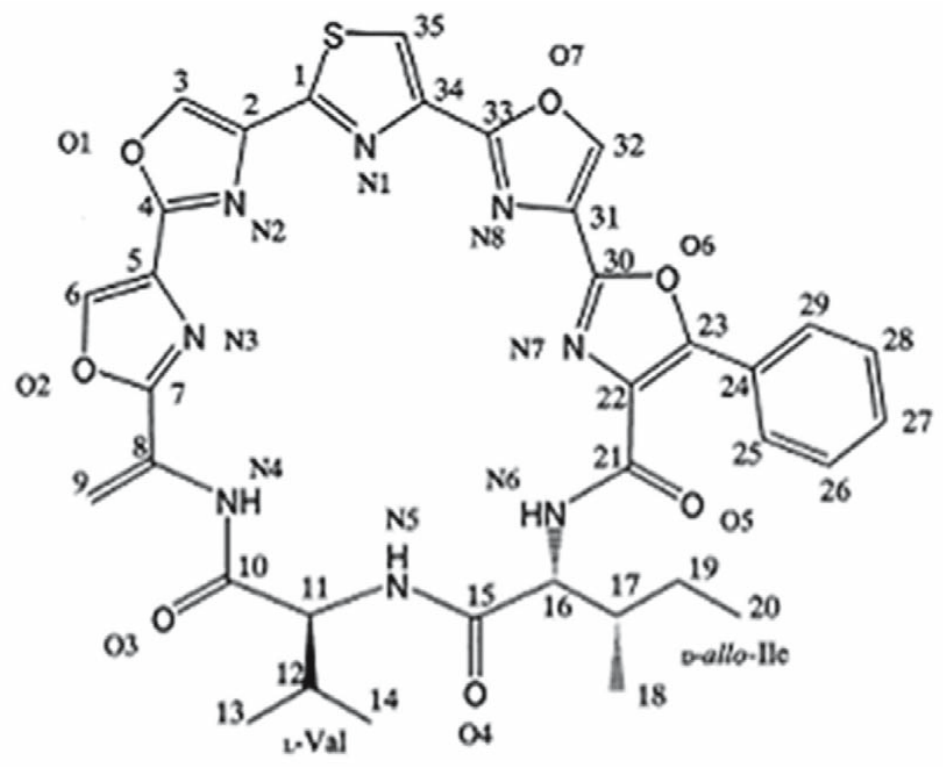

Fig. 8 Mechercharmycin A<smiles>C=CCC(C)[C@H](NC(=O)c1nc(-c2coc(C(=O)OC)n2)oc1-c1ccccc1)C(=O)NC(C(=O)NC(=O)c1nc(-c2nc(C(N)=O)co2)co1)C(C)C</smiles>

Fig. 9 Mechercharmycin B

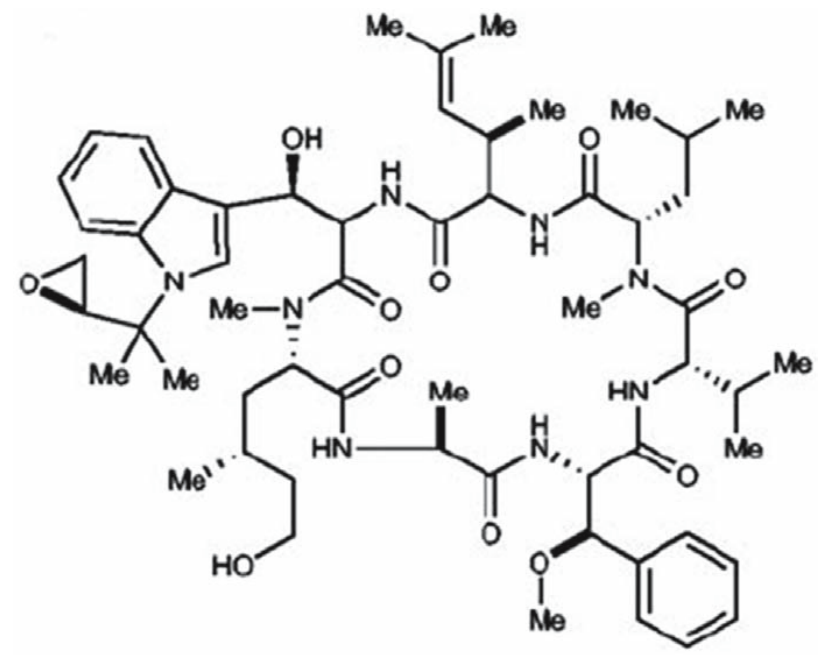

Fig. 10 Cyclomarin A

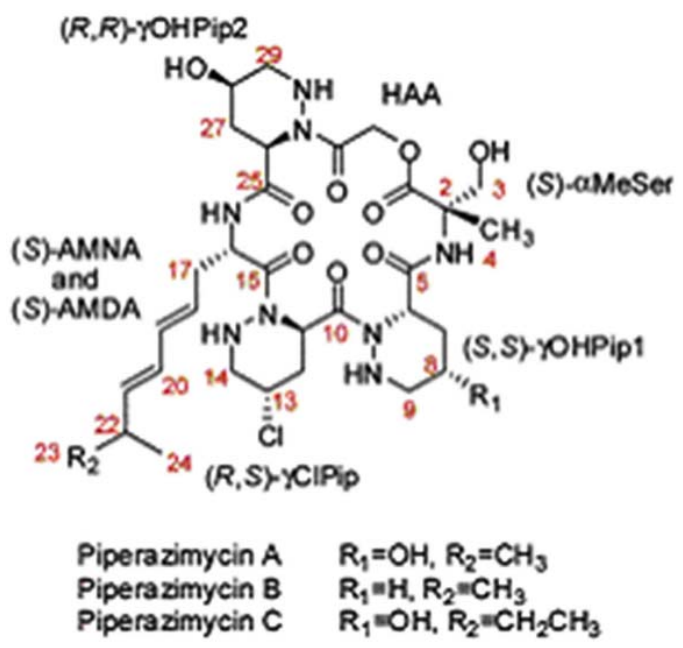

Fig. 11 Piperazimycins 
VII. Salinamides [158] A and B are bicyclic depsipeptides produced by a Streptomyces sp., CNB-091, isolated from jelly fish Cassiopeia xamachana. These metabolites are useful as antibiotic and anti-inflammatory agents.

\section{Caprolactones}

Two new caprolactones R-10-methyl-6-undecanolide and (6R,10S)-10-methyl-6-dodeconolide [159] are produced by a marine Streptomyces sp. isolate B6007. These caprolactones show a moderate phytotoxicity and low cytotoxocity against cancer cells.

\section{Butenolides}

Streptoverticillium luteoverticillatum produces four butenolides [160]. These butenolides show cytotoxicity against the murine lymphoma P388 and human leukemia K562 cell lines. This is the first report of isolation of butenolides from the marine ecosystem, which possess cytotoxic activity.

\section{Polycyclic xanthones}

IB-00208 [161] is a polycyclic xanthone isolated from the culture of Actinomadura. This compound possesses cytotoxicity against tumor cell lines and bactericidal activity against gram-positive bacteria.

\section{Piericidins}

Piericidins C7 and C8 [162] show selective cytotoxicity against rat glia cells transformed with the adenovirus EIA gene and neuro-2a mouse neuroblastoma cells. These compounds are produced by a marine Streptomyces sp.

8. Quinones

I. Resistomycin [163] (Fig. 12), an antibiotic related to quinones, is produced by Streptomyces corchorusii AUBN(1)/7. This is an inhibitor of HIV-1 protease.

II. Tetracenomycin D [164] (Fig. 13) is an anthraquinone antibiotic also produced by Streptomyces corchorusii AUBN(1)/7. It shows cytotoxicity against cell line HMO2 (gastric adenocarcinoma) and HepG2 (hepatic carcinoma) and possesses weak antibacterial activities against gram-positive and gram-negative bacteria.

III. Resistoflavine [165, 166] (Fig. 14) is produced by Streptomyces chibaensis AUBN(1)/7. It shows cytotoxicity against cell line HMO2 (gastric adenocarcinoma) and HepG2 (hepatic carcinoma) and possess-

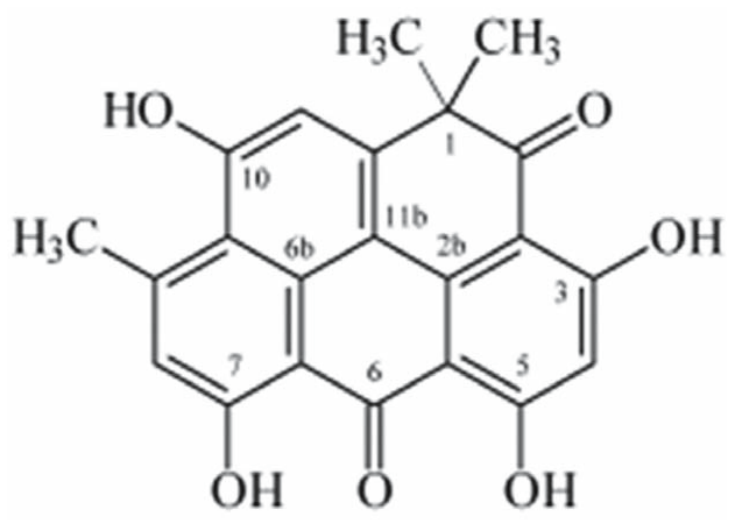

Fig. 12 Resistomycin<smiles>Cc1cc(O)cc2cc3c(c(O)c12)C(=O)c1c(O)cc(O)cc1C3=O</smiles>

Fig. 13 Tetracenomycin D<smiles>Cc1cc(O)c2c3c1C(=O)C=C1C(C)(C)C(=O)c4c(O)cc(O)c(c4-2)C13O</smiles>

$\mathrm{R}=\mathrm{H}$

Fig. 14 Resistoflavine

es weak antibacterial activities against gram-positive and gram-negative bacteria.

IV. Komodoquinone A [167] (Fig. 15) is a neuritogenic anthracycline isolated from the fermentation broth of a marine Streptomyces sp. K53. It induces cell differentiation in the neuroblastoma cell line, Neuro2A and arrests cell cycle at the G1 phase.

V. Himalomycins A and B [168] (Fig. 16) are two new quinone antibiotics from a Streptomyces isolate, B6921. Himalomycins exhibit strong antibacterial activity against Bacillus subtilis, Streptomyces 


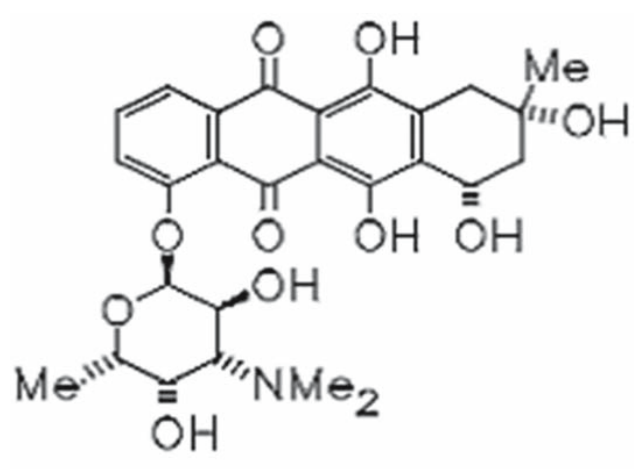

Fig. 15 Komodoquinone A

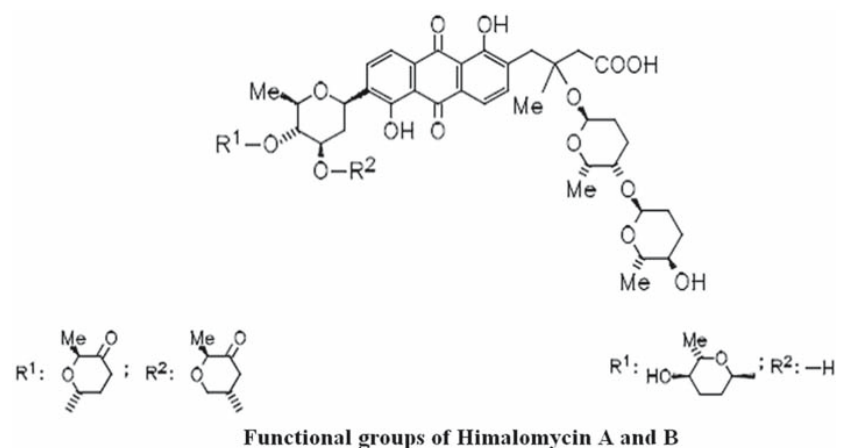

Fig. 16 Himalomycins A and B

viridochromogenes, Staphylococcus aureus and Escherichia coli.

VI. Helquinolines [169] (Fig. 17) are new tetrahydroquinoline antibiotic isolated from culture broth of Janibacter limosus. Helquinoline shows moderate activity against Bacillus subtilis, Streptomyces virdochromogenes Tu57 and Staphylococcus aureus.

VII. CNQ-525 is a member of a new genus (tentatively called MAR4) within the family Streptomycetaceae, which produces three novel chlorinated dihydroquinones [170]. These compounds possess new carbon skeletons but are related to several previously reported metabolites of the napyradiomycin class. The metabolites possess significant antibiotic properties and cytotoxicity against cancer cells.

9. Macrolides

I. Streptomyces sp. M491 is a marine actinobacterium that produces a macrolide antibiotic named Chalcomycin A [144] (Fig. 18) and also some terpenes.

II. Some strains of Salinispora arenicola produce a series of macrolides exemplified by Arenicolide [147, 171]

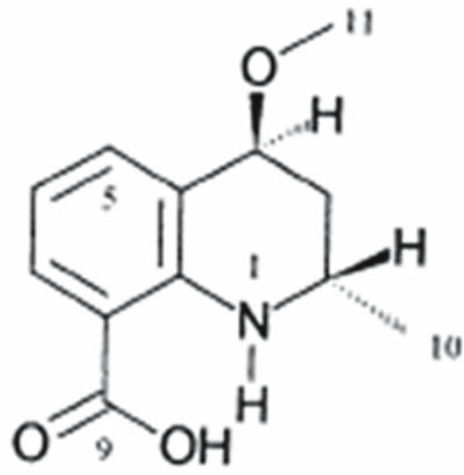

Fig. 17 Helquinoline

(Fig. 19). These possess weak antibacterial activities against drug-resistant bacteria.

III. Marinomycins [172] (Fig. 20) are polyene-like macrolides. A marine Marinispora produces these compounds, which are potent antitumor antibiotics with moderate activities against selected human tumors and drug-resistant bacterial pathogens. Marinomycin A inhibits the growth of human pathogenic bacteria such as methicillin-resistant Staphylococcus aureus and vancomycin-resistant Enterococcus faecium. These polyenes are highly photoreactive and undergo isomerization even at room light because of which their use in clinics as potential drugs has been discontinued. In spite of being polyenes, marinomycins however, do not shows antifungal activities typically associated with other polyene antibiotics.

\section{Alkaloids}

Two indolocarbazole alkaloids, K252c [173] (Fig. 21) and Arcyriaflavin A [173] (Fig. 22) are produced by a marine actinomycete Z(2)0392. Both of these alkaloids possess moderate cytotoxicity against the K562 cell line and induce apoptosis. This is the first report of the significant apoptosis inducing effect of indolocarbazole alkaloids against K562 cancer cells.

\section{Esters}

Bonactin [174] (Fig. 23) is an antimicrobial ester. Bonactin displays antimicrobial activity against gram-positive and gram-negative bacteria as well as against several fungi. Bonactin is produced by Streptomyces sp. BD21-2.

\section{Chinikomycins}

Chinikomycins A (Fig. 24) and B [175] are chlorinecontaining aromatic manumycin derivatives. They exhibit antitumor activity against different human cancer cell lines, 


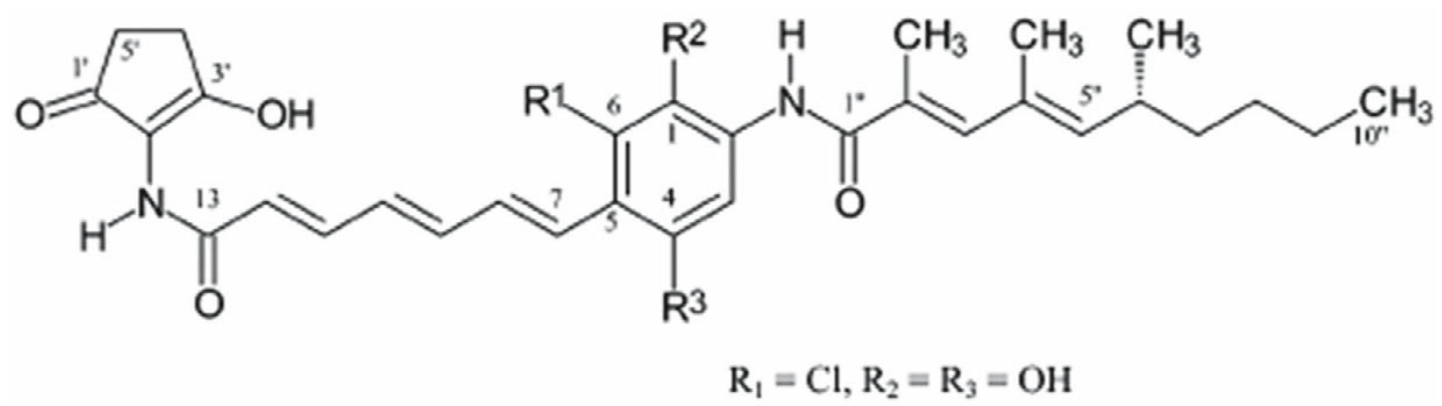

Fig. 18 Chalcomycin A

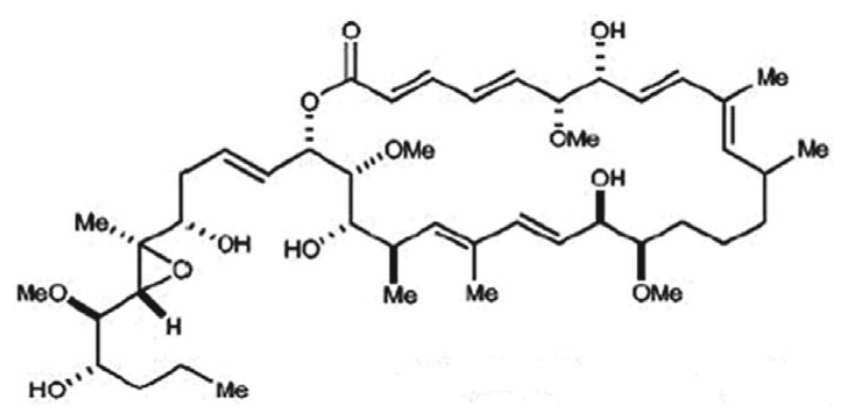

Fig. 19 Arenicolide A

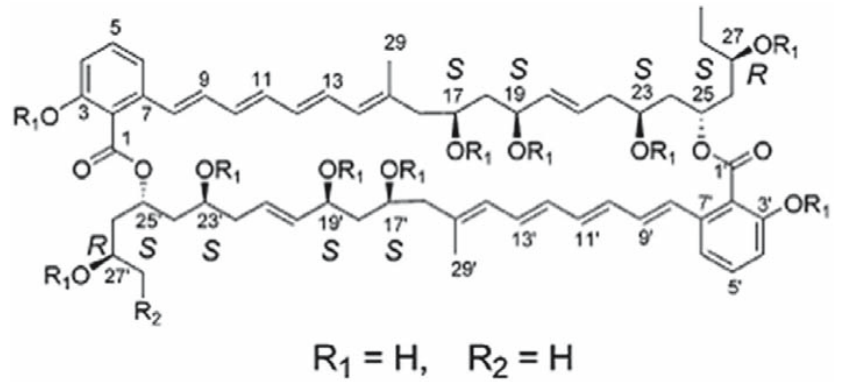

Fig. 20 Marinomycin A

but are inactive as antiviral, antimicrobial and phytotoxic agents. These compounds are produced by Streptomyces sp. isolate $\mathrm{MO} 45$.

\section{Trioxacarcins}

Trioxacarcins [176] (Fig. 25) are complex compounds showing high antibacterial activity against gram-positive and gram-negative bacteria, and some of them show high antitumor and antimalarial activities as well. Trioxacarcin A also exhibits antifungal activities. Trioxacarcin A, B and $\mathrm{C}$ are obtained from Streptomyces ochraceus and Strep-

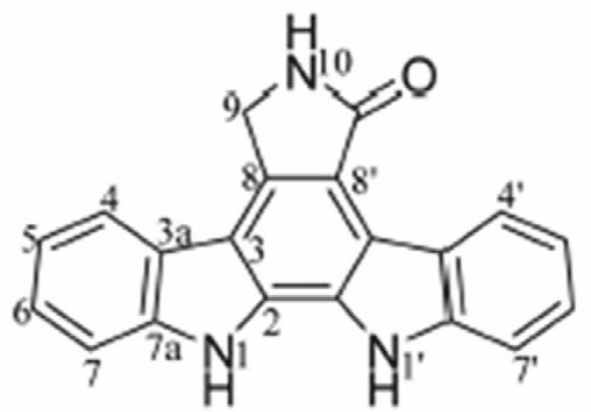

Fig. 21 K252c

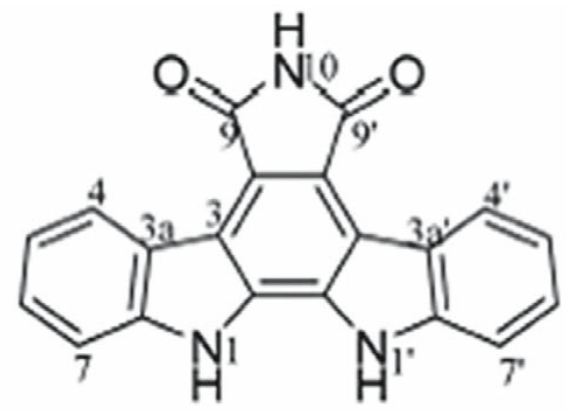

Figs. 22 Arcyriaflavin A

tomyces bottropensis. Some of these compounds possess extremely high antiplasmodial activity, which is comparable to that shown by artemisinin, the most active compound against the pathogen of malaria. The producers of trioxacarcins also biosynthesize the related metabolite, gutingimycin.

14. Methylpyridine

Streptokordin [177] a new cytotoxic compound of the methylpyridine class is isolated from the cultural broth of Streptomyces sp. KORDI-3238. It exhibits significant cytotoxicity against several human cancer cell lines but shows no growth inhibition against various microorganisms, including bacteria and fungi. 


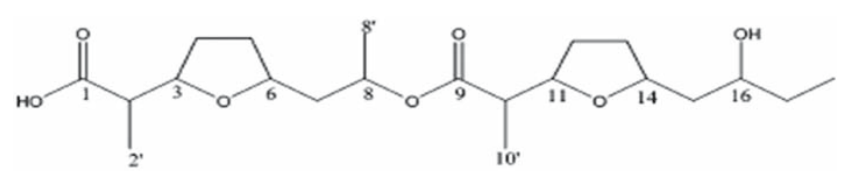

Fig. 23 Bonactin

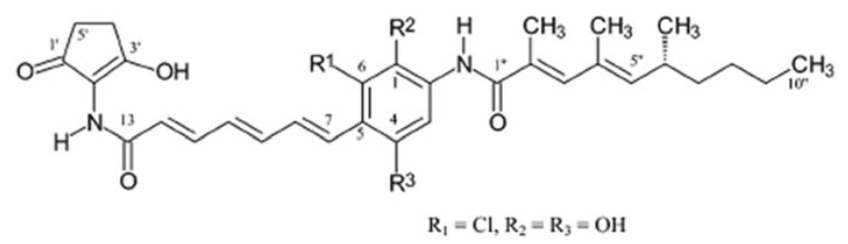

Fig. 24 Chinikomycin A $\beta$-lactam compounds which contain a four-membered $\beta$-lactam ring. The structure of $\beta$-lactam second ring allows these compounds to be classified into penicillins, cephalosporins, clavams, carbapenes and monobactans [194]. Most $\beta$-lactam compounds inhibit bacterial cell wall synthesis but others behave as $\beta$-lactamase inhibitors (e.g. cluvalanic acid) and even as antifungal agents (e.g. some clavams) [194], however salinosporamide A and aureoverticillactam show cytotoxicity against cancer cells.

\section{Enzyme inhibitors}

Some of the enzymes inhibitors reported from marine actinomycetes include:

I. Alpha amylase inhibitor from Streptomyces corchorusii subsp. rhodomarinus. subsp. nov [180].
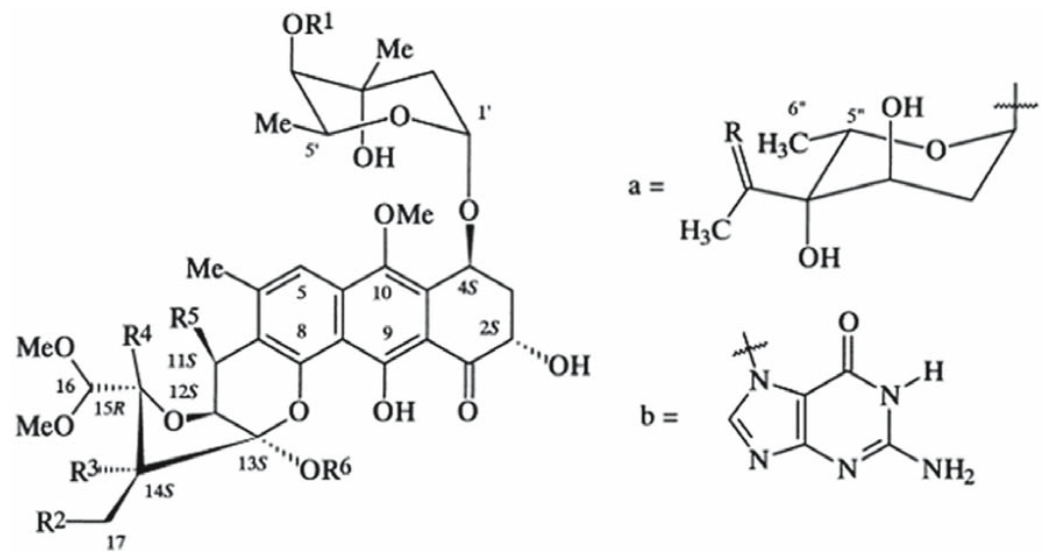

$$
\begin{aligned}
& \text { Trioxacarcin A } \mathrm{R}^{1}=\mathrm{COCH}_{3} ; \mathrm{R}^{2} \cdot \mathrm{R}^{3}=\mathrm{R}^{4} \cdot \mathrm{R}^{5}=\mathrm{O} ; \mathrm{R}^{6}=\mathrm{a}: \mathrm{R}=\mathrm{O} \\
& \text { Trioxacarcin } \mathrm{B} \quad \mathrm{R}^{1}=\mathrm{COCH}_{3} ; \mathrm{R}^{2}=\mathrm{R}^{3}=\mathrm{OH} ; \mathrm{R}^{4} \cdot \mathrm{R}^{5}=\mathrm{O} ; \mathrm{R}^{6}=\mathrm{a}: \mathrm{R}=\mathrm{O} \\
& \text { Trioxacarcin C } \mathrm{R}^{1}=\mathrm{COCH}_{3} ; \mathrm{R}^{2} \cdot \mathrm{R}^{3}=\mathrm{R}^{4}-\mathrm{R}^{5}=\mathrm{O} ; \mathrm{R}^{6}=\mathrm{a}: \mathrm{R}=\mathrm{OH}, \mathrm{H}
\end{aligned}
$$

Fig. 25 Trioxacarcins

\section{Lactams}

I. Salinosporamide A [147, 178] (Fig. 26) is produced by Salinispora tropica which is found in oceanic sediments. Salinosporamide A is a potent proteasome inhibitor used as an anticancer agent that has entered phase I of the human clinical trials for the treatment of multiple myeloma. It inhibits proteasome activity by covalently modifying the active site threonine residues of the $20 \mathrm{~S}$ proteasome.

II. Aureoverticillactam, a novel 22-atom macrocyclic lactam [179] is isolated from Streptomyces aureoverticillaris. It shows cytotoxicity against various tumor cell lines.

Salinosporamide A and aureoverticillactam are lactams from marine actinomycetes. These are distinct from

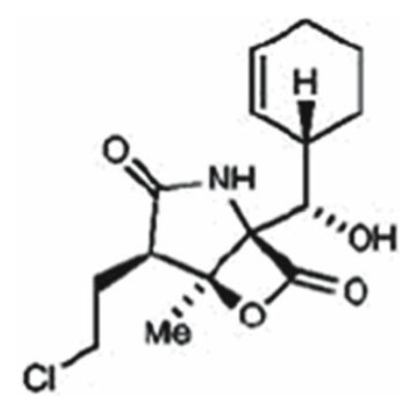

Fig. 26 Salinosporamide A

II. Pyrostatins A and B are inhibitors of n-acetyl-beta-glucosaminidase, produced by Streptomyces sp. SA-3501 [181].

III. Pyrizinostatin is an inhibitor of pyroglutamyl peptidase, isolated from culture of Streptomyces sp. SA-2289 [182]. 


\section{Conclusion}

Secondary metabolites produced from marine actinomycetes have distinct chemical structures, which may form the basis for the synthesis of new drugs. Salinispora alone produces a wide range of metabolites having different biological activities [146, 147, 171, 178]. Enrichment and selective isolation methods can also be used to isolate rare actinomycetes from marine ecological niches having the potential to biosynthesize novel bioactive compounds [140, 195-197]. A great hurdle however, in the search of these actinomycetes is that more than $90 \%$ of the organisms remain uncultivable under laboratory conditions. To explore the genomic diversity of the marine ecosystem and estimate their biosynthetic capability, the techniques of metagenomics can be used. Turbomycin is one of the first antibiotics to be discovered by metagenomics [198]. Isolation of long-chain acyltyrosine antibiotics from metagenomic libraries has also been reported [199]. Genes encoding enzymes responsible for the synthesis of secondary metabolites, are usually clustered on a contiguous piece of DNA. For expression of a single antibiotic there is a need for a large size DNA, which is a major challenge when DNA is isolated from soil, having high concentrations of humus and heavy metals as contaminants [200, 201]. But large insert metagenomic libraries can be prepared from marine samples with ease. By designing a suitable vector, which can accommodate large size inserts, it is possible to isolate novel bioactive compounds from marine unculturable actinomycetes [200, 201].

Acknowledgments The author [RS] acknowledges Council of Scientific and Industrial Research (CSIR), Government of India, for providing the Junior Research Fellowship. This work was supported by grants from the Ministry of Environment and Forests (MOEF), Government of India. Infrastructural facilities provided by Acharya Narendra Dev College are gratefully acknowledged.

\section{References}

1. Bull AT (2004) Microbial diversity and biosprospecting. ASM Press

2. Berdy J (2005) Bioactive microbial metabolites. J Antibiot (Tokyo) 58:1-26

3. Mann J (2001) Natural products as immunosuppressive agents. Nat Prod Rep 18:417-430

4. Pecznska Czoch W and Mordaski M (1988) Actinomycetes in biotechnology. Academic Press London, pp 219-283

5. Reeves AR, Post DA and Boom TJV (1998) Physical genetic map of the erythromycin producing organism Saccharopolyspora erythraea. Microbiology 144:2151-2159

6. Madduri K, Waldron C and Merlo DJ (2001) Rhamnose biosynthesis pathway supplies precursors for primary and secondary metabolism in Saccharopolyspora spinosa. J Bacteriol 183:5632-5638

7. Wanq L, Yun BS, Geirge NP, Wendt-Pienkowski E, Galm U, Oh TJ, Couqhlin JM, Zhang G, Tao M and Shen B (2007) Glycopeptide antitumor antibiotic zorbamycin from Streptomyces flavoviridis ATCC 21892: strain improvement and structure elucidation. J Nat Prod 70:402-406

8. Okami Y, Tazaki T, Katumata S, Honda K, Suzuki M and Umezawa H (1959) Studies on Streptomyces kanamyceticus, producer of kanamycin. J Antibiot (Tokyo) 12:252-256

9. Zhou J, Sun C, Wanq N, Gao R, Bai S, Zhenq H, You X and Li R (2006) Preliminary report on the biological effects of space flight on the producing strain of a new immunosuppressant kanglemycin C. J Ind Microbiol 33:707-712

10. Lomovskaya N, Fonstein L, Ruan X, Stassi D, Katz L and Hutchinson CR (1997) Gene disruption and replacement in the rapamycin producing Streptomyces hygroscopicus strain ATCC 29253. Microbiology 143:875-883

11. Steinrauf LK, Pinkerton M and Chamberlin JW (1968) The structure of nigericin. Biochem Biophys Res Commun 33:29-31

12. Wu K, Chunq L, Revill WP, Katz L and Reeves CD (2000) The FK520 gene cluster of Streptomyces hygroscopicus var. ascomyceticus (ATCC 14891) contains genes for biosynthesis of unusual polyketide extender units. Gene 251:81-90

13. Lam KS, Hesler GA, Mattei JM, Mamber SW, Forenza S and Tomita K (1990) Himastatin, a new antitumor antibiotic from Streptomyces hygrocopicus. I. Taxonomy of producing organism, fermentation and biological activity. J Antibiot (Tokyo) 43:956-960

14. Jian X, Pang X, Yu Y, Zhou X and Deng Z (2006) Identification of genes necessary for jinggangmycin biosynthesis from Streptomyces hygroscopicus 10-22. Antonie van Leeuwenhoek 90:29-39

15. Petkovic H, Cullum J, Hranueli D, Hunter IS, Peric Concha N, Pigac J, Thamchaipenet A, Vujaklija D and Long PF (2006) Genetics of Streptomyces rimosus, the oxytetracycline producer. Microbiol Mol Biol Rev 70:704-728

16. Caffrey P, Lynch S, Flood E, Finnan S and Oliynyk M (2001) Amphotericin biosynthesis in Streptomyces nodosus: deductions from analysis of polyketide synthase and late genes. Chem Biol 8:71-723

17. Hu Y and Floss HG (2004) Further studies on the biosynthesis of the manumycin type antibiotic asukamycin and the chemical synthesis of protoasukamycin. J Am Chem Soc 126:3837-3844

18. Malanicheva IA, Kozmian LI, Dudnik IuV, Stromilova LI and Novozhenov MIu (1992) Protoplast fusion in Streptomyces fradiae strains producing neomycin and tylosin. Antibiot Khimioter 37:3-7

19. Decker H and Haag S (1995) Cloning and characterization of a polyketide synthase gene from Streptomyces fradiae Tu2717, which carries the genes for biosynthesis of the anglucycline antibiotic urdamycin A and a gene probably involved in its oxygenation. J Bacteriol 177:6126-6136

20. Rorers TO and Birnbaum J (1974) Biosynthesis of fosfomycin by Streptomyces fradiae. Antimicrob Agents Chemother 5:121-132 
21. Perez-Zuniqua FJ, Seco EM, Cuesta T, Dequenhardt F, Rohr J, Vallin C, Iznaqa Y, Perez ME, Gonzalez L and Malpartida F (2004) CE-108, a new macrolide tetraene antibiotic. J Antibiot (Tokyo) 57:197-204

22. Seco EM, Zuniga FJP, Rolon MS and Malpartida F (2004) Starter unit choice determines the production of two tetraene macrolides, rimocidin and CE-108, in Streptomyces diastaticus var. 108. Chem Biol 11:357-366

23. Kamazawa S, Asami Y, Awane K, Ohtani H, Fukuchi C, Mikawa T and Hayase T (1994) Structural studies of new macrolide antibiotics, shurimycins A and B. J Antibiot ( Tokyo) 47:688-96

24. Piraee M, White RL and Vining LC (2004) Biosynthesis of the dichloroacetyl component of chloramphenicol in Streptomyces venezuelae ISP5230 genes required for halogenation. Microbiology 15:85-94

25. Krishna PSM, Venkateshwarlu G and Rao LY (1998) Studies on fermentative production of rifamycin using Amycolatopsis mediterranei. J Microbiol Biotechnol 14:689-691

26. Hughes RA, Thompson SP, Alcaraz L and Moody CJ (2004) Total synthesis of the thiopeptide amythiamicin D. Chem Commun 946-948

27. Rhee KH (2002) Isolation and characterization of Streptomyces sp. KH614 producing anti-VRE (vancomycin-resistant enterococci) antibiotics. J Gen Appl Microbiol 48:321-327

28. Schully K1, Wang J and Pettis GS (2006) Further molecular analysis of a bacteriocin produced by the sweet potato pathogen Streptomyces ipomoeae that shows inter strain inhibition. Phytopathology 96:105

29. Nomi R (1963) Streptomycin formation by intact mycelium of Streptomyces griseus. J Bacteriol 86:1220-1230

30. Perkins JB, Guterman SK, Howitt CL, Williams II VE and Pero J (1990) Streptomyces genes involved in biosynthesis of the peptide antibitotic valinomycin. J Bacteriol 172:3108-3116

31. Stroshane RM, Chan JA, Rubalcaba EA, Garretson AL, Aszalos AA and Roller PP (1979) Isolation and structure elucidation of novel griseorhodin. J Antibiot (Tokyo) 32:197-204

32. Warnick-Pickle DJ, Byrne KM, Pandey RC and White RJ (1981) Fredericamycin A, a new antitumor antibiotic. II. Biological properties. J Antibiot (Tokyo) 34:1402-1407

33. Yamaquchi H, Sato S, Yoshida S, Takada K, Itoh M, Seto H and Otake N (1986) Capuramycin, a new nucleoside antibiotic. Taxonomy, fermentation, isolation and characterization. J Antibiot (Tokyo) 39:1047-1053

34. Bruntner C, Binder T, Pathom-aree W, Goodfellow M, Bull AT, Potterat O, Puder C, Horer S, Schmid A, Bolek W, Wagner K, Mihm G and Fiedler HP (2005) Frigocyclinone, a novel angucyclinone antibiotic produced by a Streptomyces griseus strain from Antartica. J Antibiot (Tokyo) 58:346349

35. Pojer F, Wemakor E, Kammerer B, Chen H, Walsh CT, Li SM and Heide L (2003) CloQ, a prenyltransferase involved in clorobiocin biosynthesis. Biochem 100:2316-2321

36. Sun Y, Zhou X, Liu J, Bao K, Zhang G, Tu G, Kieser T and Deng Z (2002) Streptomyces nanchangensis a producer of the insecticidal polyether antibiotic nanchangmycin and the antiparasitic macrolide meilingmycin, contains multiple polyketide gene clusters. Microbiology 148:361-371
37. Malkova IV, Borisova OK, Pavlova MV, Zemlianitskaia EP and Serquuva TI (1991) In vitro activity of a new glycopeptide antibiotic eremomycin in relation to obligate anaerobic gram positive bacteria. Antibiot Khimioter 36:17-20

38. Trenin AS, Fedorova GB, Laiko AV and Dudnik IuV (2001) Increase in eremomycin production by regeneration and UVirradiation of Amycolatopsis orientalis subsp. eremomycini protoplasts. Antibiot Khimioter 46:6-11

39. Luo A, Gao C, Song Y, Tan H and Liu Z (1998) Biological responses of a Streptomyces strain producing nikkomycin to space flight space. Med Eng (Beijing) 11:411-414

40. Weitnauer G, Muhlenweg A, Trefzer A, Hoffmeister D, Submuth RD, Jung G, Welzel K, Vente A, Girreser U and Bechthold A (2001) Biosynthesis of the orthosomycin antibiotic avilamycin A: Deductions from the molecular analysis of the avi biosynthetic gene cluster of Streptomyces viridochromogenes Tu57 and production of new antibiotics. Chem Biol 8:569-581

41. Iqarashi M, Hayashi C, Homma $\mathrm{Y}$, Hattori S, Kinoshita N, Hamada M and Takeuchi T (2000) Tubelactomicin A, a novel 16-membered lactone antibiotic from Nocardia $s p$. I. Taxonomy, production, isolation and biological properties. J Antibiot (Tokyo) 53:1096-1101

42. Theriault RJ, Rasmussen RR, Kohl WL, Prokop JF, Hutch TB and Barlow GJ (1986) Benzanthrins A and B, a new class of quinone antibiotics. I. Discovery, fermentation and antibacterial activity. J Antibiot (Tokyo) 39:1509-1514

43. Omura S (1986) Philosophy of new drug discovery. Microbiol Rev 50:259-279

44. Ylihonko K, Tuikkanen J, Jussila S, Cong L and Mantsala P (1996) A gene cluster involved in nogalamycin biosynthesis from Streptomyces nogalater: sequence analysis and complementation of early block mutations in the anthracycline pathway. Mol Gen Genet 251:113-120

45. Raty K, Hautala A, Torkkell S, Kantola J, Mantsala P, Hakala J and Ylihonko K (2002) Characterization of mutations in aclacinomycin, a non-producing Streptomyces galilaeus strains with altered glycosylation patterns. Microbiology 148:3375-3384

46. Nakata M, Saito M, Inouye Y, Nakamura S, Hayakawa Y and Seto H (1992) A new anthracycline antibiotic, cinerubin R. Taxonomy, structural elucidation and biological activity. J Antibiot (Tokyo) 45:1599-1608

47. Samain D, Cook JC and Rinehart KL (1982) Structure of scopafungin, a potent nonpolyene antifungal antibiotic. J Am Chem Soc 104:4129-4141

48. Ikeda H, Inoue M and Satoshi O (1982) Improvement of macrolide antibiotic producing Streptomycete strains by the regeneration of protoplasts. J Antibiot (Tokyo) 36:283-288

49. Lagard VC, Blanc V, Gil P, Naudin L, Lorenzon S, Famechon A, Jacques NB, Crouzet J and Thibaut D (1997) Pristinamycin I biosynthesis in Streptomyces pristinaespiralis: molecular characterization of the first two structural peptide synthetase genes. J Bacteriol 179:705-713

50. Kinashi H, Mori E, Hatani A and Nimi O (1994) Isolation and characterization of linear plasmids from lankacidin producing Streptomyces species. J Antibiot (Tokyo) 47:1447-1455

51. Konoshenko GI, Avraleva IV, Anisova LN and Orlova TI (1994) Biologically active substances by a number of strains of the actinomycin C producer Streptomyces chyrsomallus. Antibiot Khimioter 39:22-25 
52. Jingsong YE, Dickens ML, Plater R, Yun LI, Jessica L and Strohl WR (1994) Isolation and sequence analysis of polyketide synthase genes from the daunomycin producing Streptomyces sp. strain C5. J Bacteriol 176:6270-6280

53. Hara O and Hutchinson CR (1992) A macrolide 3-O-acyltransferase gene from the midecamycin producing species Streptomyces mycarofaciens. J Bacteriol 174: 5141-5144

54. Ikeda $\mathrm{H}$, Nonomiya $\mathrm{T}$, Usami $\mathrm{M}$, Ohta $\mathrm{T}$ and Omura $\mathrm{S}$ (1999) Organization of the biosynthetic gene cluster for the polyketide anthelmintic macrolide avermectin in Streptomyces avermitilis. Biochem 96:9509-9514

55. Ikeda H and Omura S (1995) Control of avermectin biosynthesis in Streptomyces avermitilis for the selective production of a useful component. J Antibiot (Tokyo) 48:549-562

56. Iquarashi M, Kinoshita N, Ikeda T, Kameda M, Hamada M and Takeuchi T (1997) Resormycin, a novel herbicidal and antifungal antibiotic produced by a strain of Streptomyces platensis. I. Taxonomy, production, isolation and biological properties. J Antibiot (Tokyo) 50:1020-1025

57. Kawakami Y, Matsuwaka S, Otani T, Kondo H and Nakamura S (1978) Ileumycin, a new antibiotic against Glomerella cingulata. J Antibiot (Tokyo) 31:112-116

58. Mao Y, Varoglu M and Sherman DH (1999) Molecular characterization and analysis of the biosynthetic gene cluster for the antitumor antibiotic Mitomycin C from Streptomyces lavendulae NRRL 2564. Chem Biol 6:251-263

59. Johnson LE and Dietz A (1969) Lomofungin, a new antibiotic produced by Streptomyces lomondensis sp. Appl Microbiol 17:755-759

60. Johnson LE and Dietz A (1968) Kalafungin, a new antibiotic produced by Streptomyces tanashiensis strain kala. Appl Microbiol 16:1815-1821

61. Cassinelli G, Cotta E, D'Amico G, Della Bruna C, Grein A, Mazzoleni R, Ricciardi ML and Tintinelli R (1970) Thiamycins, new anthelmintic and antiprotozoal antibiotics produced by Streptomyces michiganensis var. amylolyticus var. nova. Arch Mikrobiol 70:197-210

62. Bruna CD, Ricciardi ML and Sanfilippo A (1973) Axenomycins, new cestocidal antibiotics. Antimicrob Agents Chemother 3:708-710

63. Wu RY, Yanq LM, Yokoi T and Lee KH (1988) Neihumicin, a new cytotoxic antibiotic from Micromonospora neihuensis. I. The producing organism, fermentation, isolation and biological properties. J Antibiot (Tokyo) 41:481-487

64. Ohta T and Haseqawa M (1993) Analysis of the self defense gene $(\mathrm{fmrO})$ of a fortimicin A (astromicin) producer, Micromonospora olivasterospora: comparison with other aminoglycoside-resistance encoding genes. Gene 127:63-69

65. Escalante L, Gonzalez R, Obregon AM and Sanchez S (1992) Carbon catabolite regulation of gentamicin formation. J Antibiot (Tokyo) 45:465-469

66. Ross A and Schugerl K (2005) Tetracycline production by Streptomyces aureofaciens: the time lag of production. Appl Microbiol Biotechnol 29:174-180

67. Gauze GF, Preobrazhenskaia TP, Ivanitskaia LP and Kovalenkova VK (1960) Synthesis of new antibiotic monomycin by Actinomyces circulatus var. monomycini cultures. Antibiotiki 5:3-6

68. Malanicheva IA, Kozmian LI, Dudnik IuV, Florova GIa and Orekhov AV (1992) Comparative study of Streptomyces producer of aminoglycoside antibiotics, monomycin and kanamycin and the strain 344 obtained by fusion of their protoplasts by the method of restrictive total DNA fingerprinting. Antibiot Khimioter 37:5-7

69. Kumaqai K, Fukui A, Tanaka S, Ikemoto M, Moriquchi K and Nabeshima S (1993) PC-766B, a new macrolide antibiotic produced by Nocardia brasiliensis. II. Isolation, physico-chemical properties and structures elucidation. J Antibiot (Tokyo) 46:1139-1144

70. Xia H, Wanq Y, and Sun J (1994) Characterization of polyketide ketoreductase gene (MPKR) from midecamycin producing strain (Streptomyces mycarofaciens 1748). Chin J Biotechnol 10:169-178

71. Schlegel L, Merad B, Rostane H, Broc V and Bouvet A (2001) In vitro activity of midecamycin diacetate, a 16-membered macrolide, against Streptococcus pyogenes isolated in France, 1995-1999. Clin Microbiol Infect 7:362-366

72. Karwowski JP, Jackson M, Maus ML, Kohl WL, Humphrey PE and Tillis PM (1991) Dunaimycins, a new complex of spiroketal 24-membered macrolides with immunosuppressive activity. I. Taxonomy of the producing organisms, fermentation and antimicrobial activity. J Antibiot (Tokyo) 44: 1312-1317

73. Mitchell JI, Loqan PG, Cushinq KE and Ritchie DA (1990) Novobiocin-resistance sequences from the novobiocin producing strain Streptomyces niveus. Mol Microbiol 4: 845-849

74. Naumova IB, Diqumbai K, Potekhina NV, Shashkov AS and Terekhova LP (1986) Teichoic acid from the cell wall of $A c$ tinomadura carminata a producer of the antibiotic carminomycin. Bio Org Khim 12:670-678

75. Terekhova LP, Galatenko OA, Preobrazhenskaia TP, Tolstykh IV, Ol'Khovatova OL, Malkina ND and Rubtsova EV (1991) Actinomadura species as antibiotic producers. Antibiot Khimioter 36:3-5

76. Ashton RJ, Keniq MD, Luk K, Planterose DN and Scott-Wood G (1990) MM46115, a new antiviral antibiotic from Actinomadura pelletieri. Characteristics of the producing cultures, fermentation, isolation, physiochemical and biological properties. J Antibiot (Tokyo) 43:1387-1393

77. Nishiyama Y, Suqawara K, Tomita K, Yamamoto H, Kamei $\mathrm{H}$ and Oki T (1993) Verucopeptin, a new antitumor antibiotic active against B16 melanoma. I. Taxonomy, production, isolation, physico-chemical properties and biological activity. $\mathrm{J}$ Antibiot (Tokyo) 46:921-927

78. Abe N, Nakakita Y, Nakamura T, Enoki N, Uchida H and Munekata M (1993) Novel antitumor antibiotics, saptomycins. I. Taxonomy of the producing organism, fermentation, HPLC analysis and biological activities. J Antibiot (Tokyo) 46:1530-1535

79. Abe N, Nakakita Y, Nakamura T, Enoki N, Uchida H, Takeo O and Munekata M (1993) Novel cytocidal compounds, oxapropalines from Streptomyces sp. G324 producing lavendamycin. I. Taxonomy of the producing organism, fermentation, isolation and biological activities. J Antibiot (Tokyo) 46:1672-1677

80. Balitz DM, Bush JA, Bradner WT, Doyle TW, Herron FAO and Nettleton DE (1982) Isolation of lavendamycin - A new antibiotic from Streptomyces lavendulae. J Antibiot (Tokyo) $3: 259-265$ 
81. Arai T, Yazawa K, Mikami Y, Kubo A and Takahashi K (1976) Isolation and characterization of satellite antibiotics mimosamycin and chlorocarcins from Streptomyces lavendulae, streptothricin source. J Antibiot (Tokyo) 4:398-407.

82. Komori T, Ezaki ME, Kohsaka M, Aoki H and Imanaka H (1985) Lavendomycin, a new antibiotic. I. Taxonomy, isolation and characterization. J Antibiot (Tokyo) 38:691-698

83. Umezawa I, Tronouet C, Funayama S, Okada K and Komiyama K (1985) A novel antibiotic, sohbumycin. Taxonomy, fermentation, isolation and physico-chemical and biological characteristiocs. J Antibiot (Tokyo) XXXVIII:967-971

84. Ishibashi M, Funayama S, Anraku Y, Komiyama K and Omura S (1991) Novel antibiotics furaquinocins C, D, E, F, G and H. J Antibiot (Tokyo) 44:390-395

85. Karwowski JP, Jackson M, Theriault RJ, Prokop JF, Maus ML, Hansen CF and Hensey DM (1988) Arizonins, a new complex of antibiotics related to kalafungin. I. Taxonomy of the producing culture, fermentation and biological activity. J Antibiot (Tokyo) 9:1205-1211

86. Jackson M, Karwowski JP, Theriault RJ, Fernandes PB, Semon RC and Kohl WL (1987) Coloradocin, an antibiotic from a new Actinoplanes. I. Taxonomy, fermentation and biological properties. J Antibiot (Tokyo) 40:1375-1382

87. Parenti F, Beretta G, Berti M and Arioli V (1978) Teichomycins, new antibiotics from Actinoplanes techomyceticus nov. sp. I. Description of the producer strain, fermentation studies and biological properties. J Antibiot (Tokyo) XXXI:276-283

88. Parenti F, Pagani H and Beretta G (1975) Lipiarmycin, a new antibiotic from Actinoplanes. I. Description of the producer strain and fermentation studies. J Antibot (Tokyo) 4:247252

89. Itoh Y, Torikata A, Katayama C, Haneishi T and Arai M (1981) Candiplanecin, a new antibiotic from Ampullariella regularis subsp. mannitophila subsp. nov. II. Isolation, physico-chemical characterization and biological activities. J Antibiot (Tokyo) 34:934-937

90. Takasawa S, Kawamoto I, Okachi R, Kohakura M, Yahashi $\mathrm{R}$ and Nara T (1975) A new antibiotic victomycin (XK 491-B-2). II. Isolation, purification and physiochemical and biological properties. J Antibiot (Tokyo) XXVIII:366-371

91. Pandey RC, Toussaint MW, McGuire JC and Thomas MC (1989) Maggiemycin and anhyromaggiemycin: two novel anthracyclinone antitumor antibiotics: isolation, structures, partial synthesis and biological properties. J Antibiot (Tokyo) 42:1567-1577

92. Tokoro Y, Isoe T and Shindo K (1999) Gilvusmycin, a new antitumor antibiotic related to CC-1065. J Antibiot (Tokyo) 52:263-268

93. Umezawa I, Komiyama K, Oka H, Okada K, Tomisaka S, Miyano T and Takano S (1984) A new antibiotic, kazusamycin. J Antibiot (Tokyo) 37:706-711

94. Komiyama K, Funayama S, Anraku Y, Ishibashi M, Takahashi Y, Kawakami T and Omura S (1991) A new antibiotic, Okicenone. I. Taxonomy, fermentation, isolation and biological characteristics. J Antibiot (Tokyo) 44:814-818

95. Hanada M, Kaneta K, Nishiyama Y, Hoshino Y, Konishi M and Oki T (1991) Hydramycin: a new antitumor antibiotic. Taxonomy, isolation, physico-chemical properties, structure and biological activity. J Antibiot (Tokyo) 44:824-831
96. Schneider A, Spath J, Mack SB and Zeeck A (1996) New cineromycins and musacins obtained by metabolite pattern analysis of Streptomyces griseoviridis (FH-S1832). II. Structure elucidation. J Antibiot (Tokyo) 49:438-446

97. Stephan H, Kempter C, Metzger JW, Jung G, Potterat O, Pfefferle C and Fiedler HP (1996) Kanchanamycins, a new polyol macrolide antibiotics produced by Streptomyces olivaceus Tu 4018. II. Structure elucidation. J Antibiot (Tokyo) 49:765-769

98. Fiedler PH, Rohr J and Zeeck A (1986) Elloramycins B, C, D, E and F: Minor congeners of the elloramycin producer Streptomyces olivaceus. J Antibiot (Tokyo) 6:856-859

99. Yokomizo K, Miyamoto Y, Nagao K, Kumagae E, Habib ESE, Suzuki K, Harada S and Uyeda M (1998) Fattiviracin A1, a novel antiviral agent produced by Streptomyces microflavus strain no. 2445. II. Biological properties. J Antibiot (Tokyo) 51:1035-1039

100. Reis SA, Moussatche N and Damaso CR (2006) FK506, a secondary metabolite produced by Streptomyces, presents a novel antiviral activity against orthopoxvirus infection in cell culture. J Appl Microbiol 100:1373-1380

101. Pamoukian CRD and Facciotti MCR (2004) Production of the antitumoral retamycin during continuous fermentations of Streptomyces olindensis. Biochem 39:2249-2255

102. Thiericke R and Zeeck A (1988) Biosynthesis of manumycin: Origin of the polyene chains. J Antibiot (Tokyo) 5: 694-696

103. Heinstein P (1981) Mechanism of action of granaticin: Inhibition of ribosomal RNA maturation and cell cycle specificity. J Pharm Sci 71:197-200

104. James PD, Edwards C and Dawson M (1991) The effects of temperature, $\mathrm{pH}$ and growth rate on secondary metabolism in Streptomyces thermoviolaceus grown in a chemostat. J Gen Microbiol 137:1715-1720

105. Recio E, Colinas A, Rumbero A, Aparicio JF and Martin JF (2004) PI factor, a novel type quorum-sensing inducer elicits pimaricin production in Streptomyces natalensis. J Biol Chem 279:41586-41593

106. Prikrylova V, Samoukina GV, Kandybin NV, Ujhelyiova L and Varkonda K (1992) Pesticidal activity of virginiamycins S1 and M1. Folia Microbiol (Praha) 37:386-388

107. Rezanka T, Vancurova I, Kristufek V, Koza T, Caslavska J, Prikrylova V and Blumauerova M (1992) Taxonomic studies of Streptomyces virginiae mutants overproducing virginiamycin M1. Folia Microbiol (Praha) 37: $105-110$

108. Wezel GP, Krabben P, Traag BA, Keijser BJF, Kerste R, Vijgenboom E, Heijnen JJ and Kraal B (2006) Unlocking Streptomyces spp. for use as sustainable industrial production platforms by morphological engineering. Appl Environ Micobiol 72:5283-5288

109. Hiquashide E, Hatano K, Shibata M and Nakazawa K (1968) Enduracidin, a new antibiotic. I. Streptomyces fungicidicus No.B5477, an enduracidin producing organism. J Antibiot (Tokyo) 21:126-137

110. Xu M, Zhu Y, Jin Z, Wu H, Li X, Yanq Y, Jiao R, Jianq W, Wu H, Tian W, Bai X and Zha O (2006) Glycine origin of the methyl subsituent on C7'-N of octodiose for the biosynthesis of apramycin. Sci China C Life Sci 49:362-369 
111. Remsinq LL, Gonzalez AM, Nur-e-Alam M, FernandezLozano MJ, Brana AF, Rix U, Oliveira MA, Mendez C, Salas JA and Rohr J (2003) Mithramycin SK, a novel antitumor drug with improved therapeutic index, mithramycin SA and demycarosyl-mithramycin SK: three new products generated in the mithramycin producer Streptomyces argillaceus through combinatorial biosynthesis. J Am Chem Soc 125:5745-5753

112. Zhanq Q, Gould SJ and Zabriskie TM (1998) A new cytosine glycoside from Streptomyces griseochromogenes produced by the use of in vivo of enzyme inhibitors. J Nat Prod 61:648-651

113. $\mathrm{Hu} \mathrm{Z}$, Reid R and Gramajo H (2005) The leptomycin gene cluster and its heterologus expression in Streptomyces lividans. J Antibiot (Tokyo) 58:625-633

114. Zhu L, Ostah B, Rix U, Nur-E-Alam M, Mayers A, Luzhetskyy A, Mendez C, Salas JA, Bechthold A, Fedorenko $\mathrm{V}$ and Rohr J (2005) Identification of the function of gene lndM2 encoding a bifunctional oxygenase-reductase involved in the biosynthesis of the antitumor antibiotic landomycin E by Streptomyces globisporus 1912 supports the originally assigned structure for landomycinone. J Org Chem 70:631-638

115. Durr C, Schnell HJ, Luzhetskyy A, Murillo R, Weber M, Welzel K, Vente A and Bechthold A (2006) Biosynthesis of the terpene phenalinolactone in Streptomyces sp. Tu6071: Analysis of the gene cluster and generation of derivatives. Chem Biol 13:365-377

116. Uchihata Y, Ando N, Ikeda Y, Kondo S, Hamada M and Umezawa K (2002) Isolation of a novel cyclic hexadepsipeptide pipalamycin from Streptomyces as an apoptosis inducing agent. J Antibiot (Tokyo) 55:1-5

117. Ezaki M, Iwami M, Yamashita M, Hashimoto S, Komori T, Umehara K, Mine Y, Kohsaka M, Aoki H and Imanaka H (1985) Biphenomycin A and B, novel peptide antibiotics. I. Taxonomy, fermentation, isolation and characterization. J Antibiot (Tokyo) 38:1453-1461

118. Gebhardt K, Pukall R and Fiedler HP(2001) Streptocidins AD, novel cyclic decapeptide antibiotics produced by Streptomyces sp. Tu6071. I. Taxonomy, fermentation, isolation and biological activities. J Antibiot (Tokyo) 54:428-433

119. Zhang H, Tomodo H, Tabata N, Oohori M, Shinose M, Takahashi Y and Omura S (1999) Zelkovamycin, a new cyclic peptide antibiotic from Streptomyces sp. K96-0670. I. Production, isolation and biological activities. J Antibiot (Tokyo) 52:29-33

120. Gonzalez Holgado G, Castro Rodriguez J, Canedo Hernandez LM, Diaz M, Fernandes-Abalos JM, Trujillano I and Santamari RI (2002) Radamycin, a novel thiopeptide produced by Streptomyces sp. RSP9. I. Taxonomy, fermentation, isolation and biological activities. J Antibiot (Tokyo) 54:383-390

121. Sohda KY, Nagai K, Yamori T, Suzuki K and Tanaka A (2005) YM216391, a novel cytotoxic cyclic peptide from Streptomyces nobilis. I. Fermentation, isolation and biological activities. J Antibiot (Tokyo) 58:27-31

122. Toki S, Agatsuma T, Ochiai K, Saitoh Y, Ando K, Nakanishi S, Lokker NA, Giese NA and Matsuda Y (2001) RP-1776, a novel cyclic peptide produced by Streptomyces sp., inhibits the binding of PDGF to the extracellular domain of its receptor. J Antibiot (Tokyo) 54:405-414

123. Ubukata M, Shiraishi N, Kobinata K, Kudo T, Yamaguchi I, Osada H, Shen YC and Isono K (1995) RS-22 A, B and C: new macrolide antibiotics from Streptomyces violaceusniger. I. Taxonomy, fermentation, isolation and biological activities. J Antibiot (Tokyo) 48:289-92

124. Shindo K, Kamishohara M, Odagawa A, Matsuoka M and Kawai H (1993) Vicenistatin, a novel 20-membered macrocyclic lactam antitumor antibiotic. J Antibiot (Tokyo) 46:1076-1081

125. Bertasso M, Holzenkampfer M, Zeeck A, Stackebrandt E, Beil W and Fiedler HP (2003) Ripromycin and other polycyclic macrolactams from Streptomyces sp. Tu6239. Taxonomy, fermentation, isolation and biological activities. J Antibiot (Tokyo) 56:364-371

126. Igarashi M, Shida T, Sasaki Y, Kinoshita N, Naganawa H, Hamada M and Takeuchi T (1999) Vinylamycin, a new depsipeptide antibiotic from Streptomyces sp. J Antibiot (Tokyo) 52:873-879

127. Jacks TM, Schleim KD, Judith FR and Miller BM (1980) Cephamycin $\mathrm{C}$ treatment of induced enterotoxigenic colibacillosis (scours) in calves and piglets. Antibiot Chemother 18:397-402

128. Challis GL and Hopwood DA (2003) Synergy and contingency as driving forces for the evolution of multiple secondary metabolite production by Streptomyces species. Prod Nat Acad Sci USA 100:14555-14561

129. Watve MS, Tckoo R, Jog MM and Bhole BD (2001) How many antibiotics are produced by the genus Streptomyces? Arch Microbiol 176:386-390

130. Williams ST, Sharpe ME and Holt JG (1989) Bergey's manual of systematic bacteriology, Vol. 4

131. Carlos F (2003) Multiple drug resistant bacteria. Horizon, Scientific Press

132. Ekwenye UN and Kazi E (2007) Investigation of plasmid DNA and antibiotic resistance in some pathogenic organism. Afr J Biotechnol 6:877-880

133. Lam KS (2006) Discovery of novel metabolites from marine actinomycetes. Curr Opin Microbiol 9:245-251

134. Fenical W and Jensen PR (2006) Developing a new resource for drug discovery: marine actinomycete bacteria. Nat Chem Biol 2:666-673

135. Ward AC and Bora N (2006) Diversity and biogeography of marine actinobacteria. Curr Opin Microbiol 9:279-286

136. Salmon CE, Magarvey NA and Sherman DH (2003) Merging the potential of microbial genetics with biological and chemical diversity: an even brighter future for marine natural product drug discovery. Nat Prod Rep 21:105-121

137. Helmke E and Weyland H (1983) Rhodococcus marinonascens sp. nov; an actinomycete from the sea. Int J Syst Bacteriol 34:127-138

138. Wu Z, Xie L, Xia G, Zhanq J, Nie Y, Hu J, Wanq S and Zhanq R (2005) A new tetrodotoxin producing actinomycete Nocardiopsis dassonvillei isolated from the ovaries of puffer fish Fugu rubripes. Toxicon 45:851-859

139. Stach JE, Maldonado LA, Ward AC, Goodfellow M and Bull AT (2003) New primers for the class actinobacteria: 
application to marine and terrestrial environments. Environ Microbiol 5:828-841

140. Mincer TJ, Fenical W and Jensen PR (2005) Culture dependent and culture independent diversity within the obligate marine actinomycete genus Salinispora. Appl Environ Microbiol 71:7019-7028

141. Tringe SG, Von Mering C, Kobayashi A, Salamov AA, Chen K, Cheng HW, Podar M, Short JM, Mathur EJ and Detter JC (2005) Comparative metagenomics of microbial communities. Science 308:554-557

142. Cho JY, Kwon HC, Williams PG, Jensen PR and Fenical W (2006) Azamerone, a terpenoid phthalazinone from a marine derived bacterium related to the genus Streptomyces (Actinomycetales). Org Lett 8:2471-2474

143. Macherla VR, Liu J, Bellows C, Teisan S, Nicholson B, Lam KS and Potts BCM (2005) Glaciapyrroles A, B and $\mathrm{C}$ pyrrolosesquiterpenes from a Streptomyces sp. isolated from an Alaskan marine sediment. J Nat Prod 68:780783

144. Wu SJ, Fotso S, Li F, Qin S and Laatsch H (2007) Amorphane sesquiterpenes from a marine Streptomyces sp. J Nat Prod 70:304-306

145. Hardt IH, Jensen PR and William F (2000) Neomarinone and new cytotoxic marinone derivatives, produced by a marine filamentous bacterium (Actinomycetales). Science 41:2073-2076

146. William PG, Asolkar RN, Kondratyuk T, Pezzuto JM, Jensen PR and Fenical W (2007) Saliniketals A and B, bicyclic polyketides from the marine actinomycete Salinispora arenicola. J Nat Prod 70:83-88

147. Jensen PR, Williams PG, Oh DC, Zeigler L and Fenical W (2007) Species-specific secondary metabolite production in marine actinomycetes of the genus Salinispora. Appl Environ Microbiol 73:1146-1152

148. Bister B, Bischoff D, Strobele M, Riedlinger J, Reicke A, Wolter F, Bull AT, Zahner H, Fiedler HP and Sussmuth RD (2004) Abyssomicin C a polycyclic antibiotic from a marine Verrucosispora strain as an inhibitor of the p-aminobenzoic acid/tetrahydrofolate biosynthesis pathway. Chem Int Ed 43:2574-2576

149. Sujatha P, Bapi Raju KV and Ramana T (2005) Studies on a new marine Streptomycete BT 408 producing polyketide antibiotic SBR-22 effective against methicillin resistant Staphylococcus aureus. Microbiol Res. 160:119-126

150. Asolkar RN, Jensen PR, Kauffman CA and Fenical W (2006) Daryamides A-C weakly cytotoxic polyketides from a marine derived actinomycete of the genus Streptomyces strain CNQ-085. J Nat Prod 69:1756-1759

151. Cho JY, Kwon HC, Williams PG, Kauffman CA, Jensen PR and Fenical W (2006) Actinofuranones A and B, polyketides from a marine derived bacterium related to the genus Streptomyces (Actinomycetales). J Nat Prod 69:425-428

152. Kanoh K, Matsuo Y, Adachi K, Imagawa H, Nishizawa M and Shizuri Y (2005) Mechercharmycins A and B cytotoxic substances from marine derived Thermoactinomyces sp. YM 3-251. J Antibiot (Tokyo) 58:289-292

153. Romero F, Espliego F, Perez Baz J, Garcia de Quesada T, Gravalos D, de la Calle F and Fernandez Puentes JL (1997) Thiocoraline a new depsipeptide with antitumor activity produced by a marine Micromonospora. Taxonomy, fermentation isolation and biological activities. J Antibiot (Tokyo) 50:734-737

154. Renner MK, Shen YC, Cheng XC, Jensen PR, Frankmoelle W, Kauffman CA, Fenical W, Lobkovsky E and Cladry J (1999) Cyclomarins A-C, new anti inflammatory cyclic peptides produced by a marine bacterium (Streptomyces sp.). J Am Chem Soc 121:11273-11276

155. Miller ED, Kauffman CA, Jensen PR and Fenical W (2007) Piperazimycins cytotoxic hexadepsipeptides from a marine derived bacterium of the genus Streptomyces. J Org Chem 72:323-330

156. Lee HS, Shin HJ, Jang KH, Kim TS, Oh KB and Shin J (2005) Cyclic peptides of the Nocardamine class from a marine derived bacterium of the genus Streptomyces. J Nat Prod 68:623-625

157. Matsuo Y, Kanoh K, Yamori T, Kasai H, Katsuta A, Adachi K, Shin-Ya K and Shizuri Y (2007) Urukthapelstatin A, a novel cytotoxic substance from a marine derived Mechercharimyces asporophorigenes YM11-542. J Antibiot (Tokyo) 60:251-255

158. Moore BS, Trischman JA, Seng D, Kho D, Jensen PR and Fenical W (1999) Salinamides, anti-inflammatory depsipeptides from a marine Streptomycete. J Org Chem 64:1145-1150

159. Stritzke K, Schulz S, Laatsch H, Helmke E and Beil W (2004) Novel caprolactones from a marine Streptomycete. J Nat Prod 67:395-401

160. Li DH, Zhu TJ, Liu HB, Fanq YC, Gu OO and Zhu WM (2006) Four butenolides are novel cytotoxic compounds isolated from the marine derived bacterium, Streptoverticillium luteoverticillatum 11014. Arch Pharm Res 29:624-626

161. Malet Cascon L, Romero F, Espliego Vazquez F, Gravalos D and Fernandez Puentes JL (2003) IB00208, a new cytotoxic polycyclic xanthone produced by a marine derived Actinomadura. Isolation of the strain, taxonomy and biological activities. J Antibiot (Tokyo) 56:219-225

162. Hayakawa Y, Shirasaki S, Shiba S, Kawasaki T, Matsuo Y, Adachi K and Shizuri Y (2007) Piericidins C7 and C8, new cytotoxic antibiotics produced by a marine Streptomyces sp. J Antibiot (Tokyo) 60:196-200

163. Shiono Y, Shiono N, Seo S, Oka S and Yamazaki Y (2002) Effects of polyphenolic anthrone derivatives resistomycin and hypericin on apoptois in human megakaryoblastic leukemia CMK-7cell2. Natuforsch 57:923-929.

164. Adinaryan G, Venkateshan MR, Bpiraju VV, Sujatha P, Premkumar J, Ellaiah P and Zeeck A (2006) Cytotoxic compounds from the marine actinobacterium. Bio Org Khim $32: 328-334$

165. Kock I, Maskey RP, Biabani MAF, Helmke E and Laatsch $\mathrm{H}$ (2005) 1-hydroxy-1-norresistomycin and resistoflavine methyl ether new antibiotics from marine derived Streptomycetes. J Antibiot (Tokyo) 58:530-534

166. Gorajana A, MV, Vinjamuri S, Kurada BV, Peela S, Jangam P, Poluri E and Zeeck A (2006) Resistoflavine cytotoxic compound from a marine actinomycete, Streptomyces chibaensis AUBN(1)/7. Microbiol Res 29 
167. Itoh T, Kinoshita M, Aoki S and Kobayashi M (2003) Komodoquinone A, a novel neuritogenic anthracycline from marine Streptomyces sp. KS3. J Nat Prod 66: 1373-1377

168. Maskey RP, Helmke E and Laatsch H (2003) Himalomycin $\mathrm{A}$ and $\mathrm{B}$ isolation and structure elucidation of new fridamycin type antibiotics from a marine Streptomyces isolate. J Antibiot (Tokyo) 56:942-949

169. Asolkar RN, Schroder D, Heckmann R, Lang S, Dobler IW and Laatsch H (2004) Helquinoline, a new tetrahydroquinoline antibiotic from Janibacter limosus Hell. J Antibiot (Tokyo) 57:17-23

170. Mercado IES, Davo AP, Jensen PR and Fenical W (2005) Antibiotic terpenoid chloro-dihydroquinones from a new marine actinomycete. J Nat Prod 68:904-910

171. Williams PG, Miller ED, Asolkar RN, Jensen PR and Fenical W (2007) Arenicolides A-C, 26 membered ring macrolides from the marine actinomycete Salinispora arenicola. J Org Chem 72:5025-5034

172. Kwon HC, Kauffman CA, Jensen PR and Fenical W (2006) Marinomycins A-D antitumor antibiotics of a new structure class from a marine actinomycete of the recently discovered genus "Marinispora". J Am Chem Soc.128:1622-32

173. Liu R, Zhu T, Li D, Gu J, Xia W, Fang Y, Liu H, Zhu W and Gu Q (2007) Two indolocarbazole alkaloids with apoptosis activity from a marine derived actinomycete Z2039-2. Arch Pharm Res 30:270-274

174. Schumacher RW, Talmage SC, Miller SA, Sarris KE, Davidson BS and Goldberg A (2003) Isolation and structure determination of an antimicrobial ester from a marine sediment derived bacterium. J Nat Prod 66: $1291-1293$

175. Li F, Maskey RP, Qin S, Sattler I, Fiebig HH, Maier A, Zeeck A and Laatsch H (2005) Chinikomycins A and B Isolation, structure elucidation and biological activity of novel antibiotics from a marine Streptomyces sp. isolate MO45. J Nat Prod 68:349-353

176. Maskey RP, Helmke E, Kayser O, Fiebig HH, Maier A, Busche A and Laatsch H (2004) Anticancer and antibacterial trioxacarcins with high anti-malaria activity from a marine Streptomycete and their absolute stereochemistry. J Antibiot (Tokyo) 57:771-779

177. Jeong SY, Shin HJ, Kim TS, Lee HS, Park SK and Kim HM (2006) Streptokordin a new cytotoxic compound of the methylpyridine class from a marine derived Streptomyces sp. KORDI-3238. J Antibiot (Tokyo) 59:234-240

178. Feling RH et al. (2003) Salinosporamide A: a highly cytotoxic proteasome inhibitor from a novel microbial source, a marine bacterium of the new genus Salinispora. Angew Chem Int End Eng1 42:355-357

179. Mitchell SS, Nicholson B, Teisan S, Lam KS and Potts BC (2004) Aureoverticillactam, a novel 22-atom macrocyclic lactam from the marine actinomycete Streptomyces aureoverticillatus. J Nat Prod 67:1400-1402

180. Imada C and Simidu U (1988) Isolation and characterization of an alpha amylase inhibitor producing actinomycete from marine environment. Nippon Suisan Gakkaishi 54: $1839-1845$
181. Aoyama T, Kojima F, Imada C, Muraoka Y, Naqanawa H, Okami Y, Takeuchi T and Aoyaqi T (1995) Pyrostatins A and B, new inhibitors of N-acetyl-beta-D-glucosamidase, produced by Streptomyces sp. SA3501. J Enzyme Inhib 8:223-232

182. Aoyagi T, Hatsu M, Imada C, Naganawa H, Okami Y and Takeuchi T (1992) Pyrizinostatin: a new inhibitor of pyroglutamyl peptidase. J Antibiot (Tokyo) 45: 1795-1796

183. Wendt KU and Schulz GE (1998) Isoprenoid biosynthesis: manifold chemistry catalyzed by similar enzymes. Structure 6:127-133

184. Hoeksema H and Smith CG (1961) Novobiocin. Prog Ind Microbiol 3:91-139

185. KuzuyamaT and Seto H (2003) Diversity of the biosynthesis of the isoprene units. Nat Prod Rep 20:171-183

186. Uyeda M, Mizukami M, Yokomizo K and Suzuki K (2001) Pentalenolactone I and hygromycin A, immunosuppressants produced by Streptomyces filipinensis and Streptomyces hygroscopicus. Biosci Biotechnol Biochem 65:1252-1254

187. Shin-ya K, Shimizu S, Kunigami T, Furihata K, Furihata K and Seto H (1995) a new neuronal cell protecting substance, lavanduquinocin produced by Streptomyces viridochromogenes. J Antibiot (Tokyo) 48:574-578

188. Shiomi K, Iinuma H, Hamada M, Naganawa H, Manabe M, Matsuki C, Takeuchi T and Umezawa H (1986) Novel antibiotics napyradiomycins. Production, isolation, physico-chemical properties and biological activity. J Antibiot (Tokyo) 39:487-493

189. Nakajima M, Okazaki T, Iwado S, Kinoshita T and Haneishi T (1989) New diterpenoid antibiotics spirocardins A and B. J Antibiot (Tokyo) 42:1741-1748

190. Takahiro E, Yoshiro Y and Tadao K (1999) Synthetic study on radical scavenger benthocyanin A. Nippon Kagakkai Koen Yokoshu 76:774

191. Lee DG, Yoo ID and Kim WG (2007) Differential antiviral activity of benzastatin $\mathrm{C}$ and its dechlorinated derivative from Streptomyces nitrosporeus. Bio Pharm Bull 30:795-797

192. Shinya K, Kunigami T, Kim TS, Furihata K, Hayakawa Y and Seto H (1997) Carquinostatin B, a new neuronal cell protecting substance produced by Streptomyces exfoliatus. Biosci Biotechnol Biochem 61:1768-1769

193. Baizman Er, Branstrom AA, Longley CB, Allanson N, Sofia MJ, Gange D and Goldman RC (2000) Antibacterial activity of synthetic analogues based on the disaccharide structure of moenomycin an inhibitor of bacterial transglycosylase. Microbiology 146:3129-3140

194. Liras P and Martin JF (2006) Gene clusters for $\beta$-lactam antibiotics and control of their expression: why have clusters evolved, and from where did they originate. Int Microbiol 9:9-19

195. Ghanem NB, Sabry SA, El-Sherif ZM and Abu El-Ela GA (2000) Isolation and enumeration of marine actinomycetes from seawater and sediments in Alexandria. J Gen Appl Microbiol 46:105-111

196. Jensen PR, Gontang E, Mafnas C, Mincer TJ and Fenical W (2005) Culturable marine actinomycete diversity 
from tropical Pacific ocean sediments. Environ Microbiol 7:1039-1048

197. Pisano MA, Sommer JA and Branacaccio L (2004) Isolation of bioactive actinomycetes from marine sediments using rifampicin. Appl Microbiol Biotechnol 31:609-612

198. Gillespie DE et al. (2002) Isolation of antibiotics turbomycin A and B from a metagenomic library of soil microbial DNA. Appl Environ Microbiol 68:4301-4306
199. Brady SF, Chao CJ and Clardy J (2004) Long chain N-acyltyrosine synthases from environmental DNA. Appl Environ Microbiol 70:6865-6870

200. Schmeisser C, Steele H and Streit WR (2007) Metagenomics, biotechnology with non-culturable microbes. Appl Microbiol Biotechnol 75:955-962

201. Sharma R, Ranjan R, Kapardar RK and Grover A (2005) Unculturable bacterial diversity: an untapped resource. Curr Sci 89:72-77 